\title{
Grade Retention Practices in Primary Education in Timor-Leste: A Case Study
}

By

\author{
Cidalio Leite \\ A 120 point thesis submitted in partial fulfilment of \\ the requirements for the degree of \\ Master of Education
}

Victoria University of Wellington 


\begin{abstract}
Grade retention is the practice of requiring a student who has been in a given grade level for a full school year to remain at that same grade level the following year (Jimerson, 2001; Owings \& Kaplan, 2001; Wynn, 2010). Grade retention has always been practised in primary education in Timor-Leste. This study investigates rationales behind grade retention practice in grade 1 primary education in Timor-Leste. A qualitative case study was use to investigate the mechanisms teachers use to retain or promote a student. Teachers' beliefs about grade retention, their efforts to prevent students from being retained, and factors that may inhibit students' learning are explored.
\end{abstract}

Six teachers and four principals from six primary schools in two districts participated in this study. Analysis of data that were collected by using semi-structure interviews and studying documents relating to the practice of grade retention revealed that grade retention has been inconsistently practised amongst the participating schools in Timor-Leste. Despite having poor classroom conditions for learning and low teacher qualifications, teachers continue to retain low achieving students due to their beliefs that grade retention improves students' learning.

This study suggests that classroom conditions need to be improved, and teachers' qualifications need to be upgraded in order to increase student learning while reducing grade retention. 


\section{Acknowledgement}

I wish to present my sincere appreciation to those people who have provided support and encouragement to me through the journey of undertaking this thesis.

First and foremost is my supervisor, Dr Jenny Horsley. I will be forever thankful for her valuable guidance in my learning relating to this thesis. Since the first day of supervising, she was never reluctant to discuss my writing and clarify challenging ideas. She provided me with useful feedback and motivated me along the way. Jenny had been all-round supporter. My special thanks to all the teachers and the principals who agreed to participate in this study. It has been a privilege to learn about their experiences. I would like to thank them for the time and effort they gave to make this study possible.

I wish to express particular appreciation to the support given by different sections of the university: librarians, the student learning support service, student health services, and the faculty administration who were always ready to help me.

Finally, I want to thank my wife Julieta Maria da Costa who joined me and took care of our children during my study in Wellington. She always been patient in preparing food and waiting for me until I got home from my office in the late evening. Last but not least my thanks to my children, Rene, Cidalia, Arcanjo, and Milenio who were able to cope with their own learning, as most of my time was dedicated to my own study. 


\section{Table of the contents}

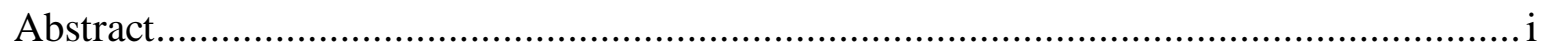

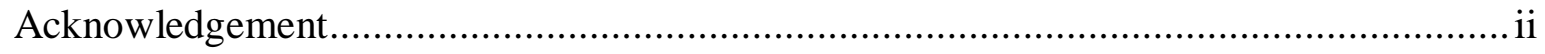

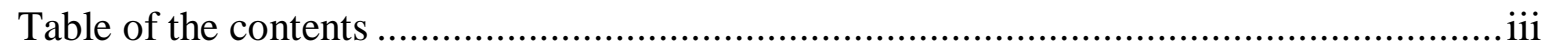

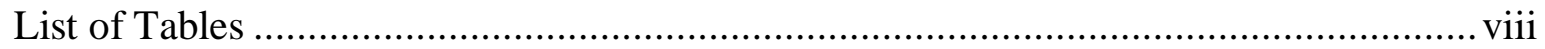

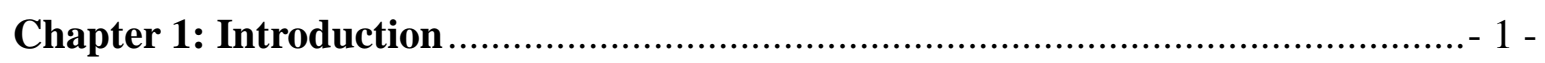

The context of the study .................................................................................. 1 -

The education system .................................................................................... 1 -

The development of education .................................................................... 1 -

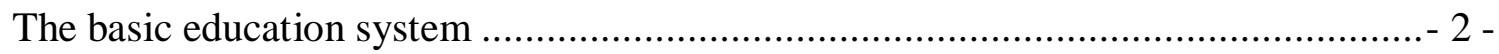

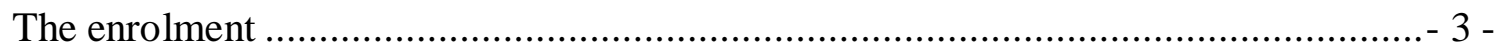

The Academic Calendar ........................................................................... 4 -

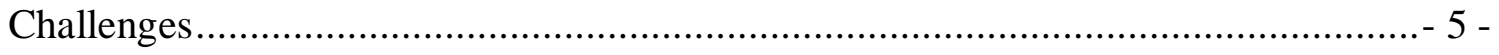

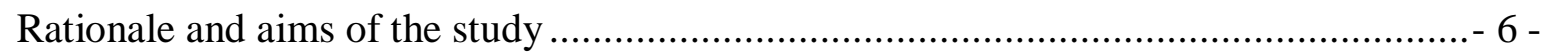

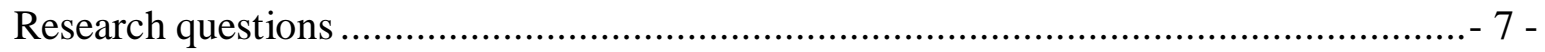

Overview of the chapters ................................................................................... 8 -

Chapter 2: Literature Review.................................................................................................... 10 -

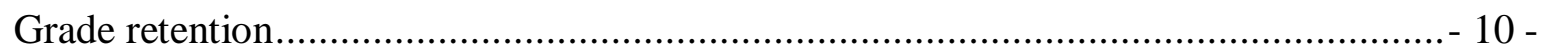

Academic performance ............................................................................ 12 -

Lower self-concept and motivation to learn .................................................... 12 -

Higher dropout rates .............................................................................. 12 -

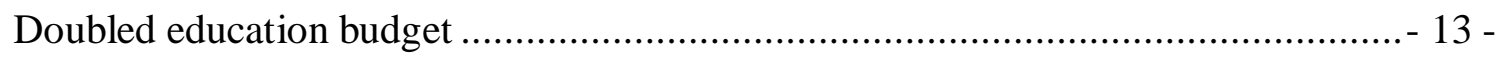


Grade retention leads to defer students' chance to work $14-$

Teacher beliefs $14-$

Assessments $16-$

Assessment in Timor-Leste $18-$

Moderation $19-$

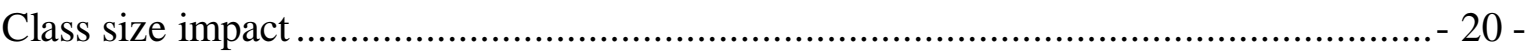

The effect of class size on teachers …........................................................ 21 -

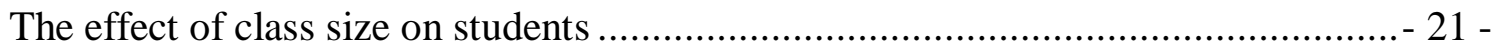

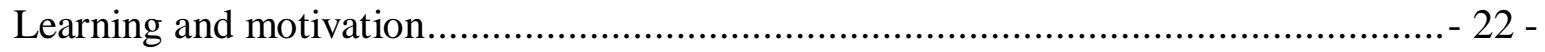

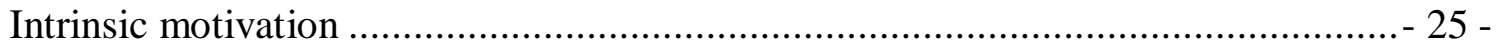

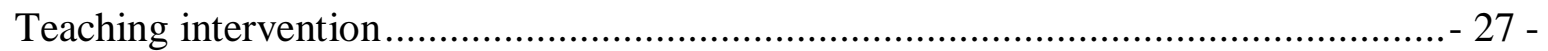

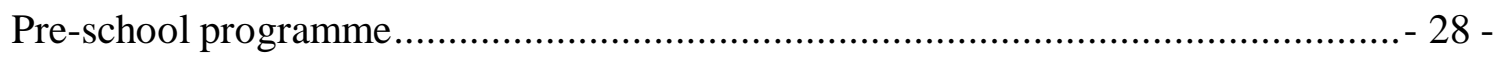

Summer school and after school programme ..................................................... 28 -

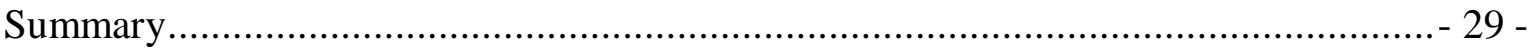

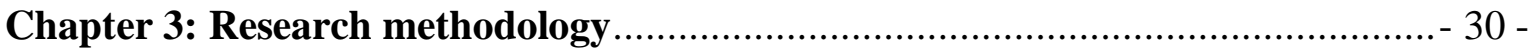

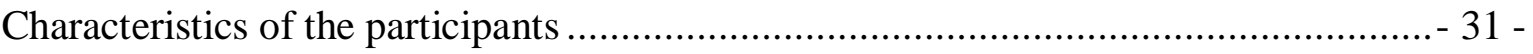

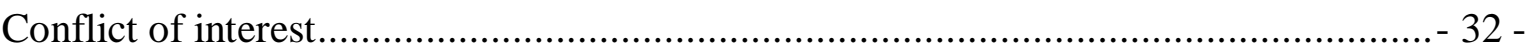

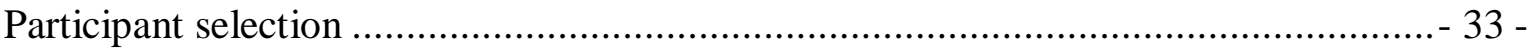

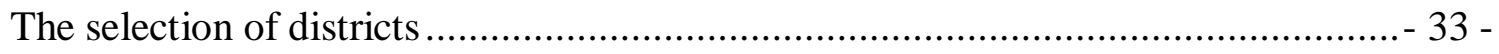

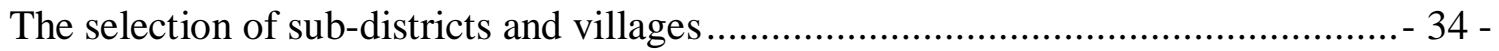

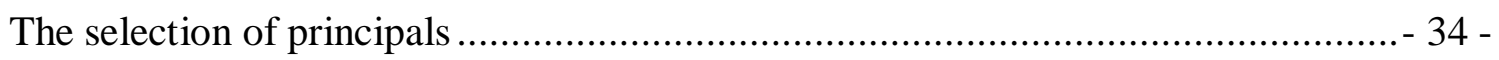

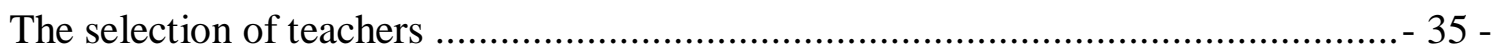




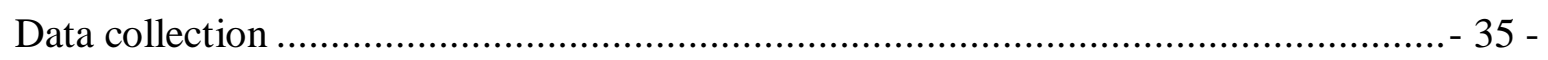

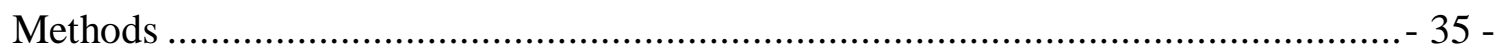

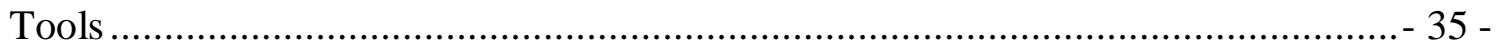

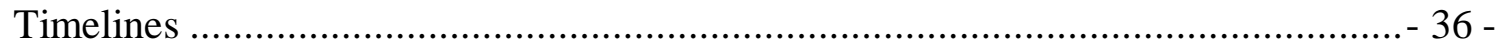

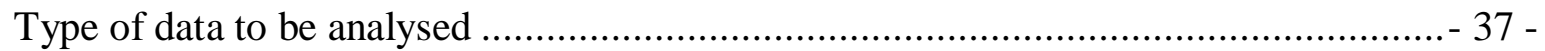

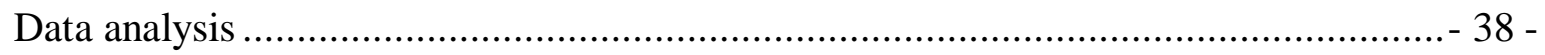

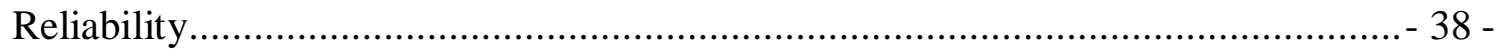

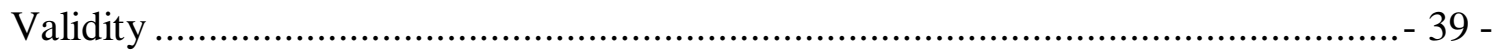

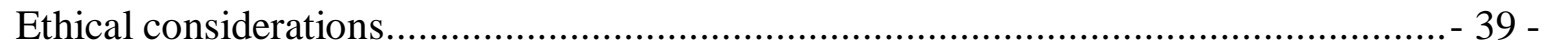

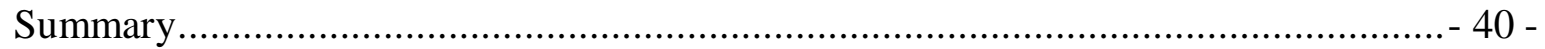

Chapter 4: Findings..................................................................................... 41 -

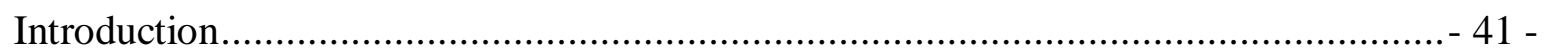

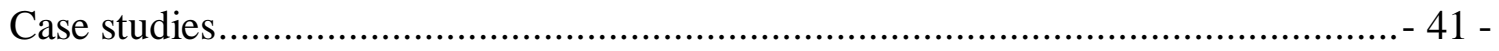

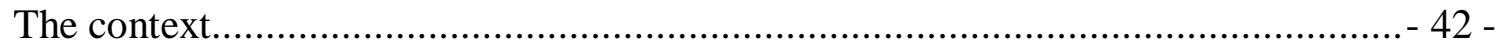

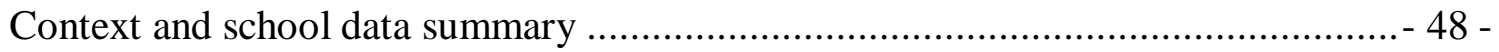

Description of participants .......................................................................... 49 -

Responses of the semi-structure interviews.................................................... 50 -

Question 1: How do grade 1 teachers determine grade promotion or retention? .......- 51 -

Question 2: What role does formative assessment have in students' learning prior to

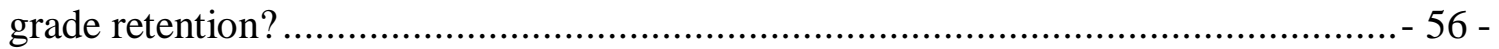

Question 3: What, if any, strategies do teachers use to improve students' learning in order to prevent them from being retained in grade 1 ? ....................................... 60 - 
Question 4: In relation to grade retention what factors do grade 1 teachers believe inhibit students' achievement of learning outcomes? $62-$

Question 5: What beliefs do grade 1 teachers hold about grade retention practices? .- 67 -

Chapter 5: Discussion of findings $79-$

Section 1: Grade promotion or retention practices $-80-$

Section 2: The role of formative assessment $86-$

Section 3: Teachers intervention $91-$

Section 4: Factors teachers and principals believe inhibit student achievement $94-$

Section 5: Teachers' and principals' beliefs about grade retention $101-$

Chapter 6: Recommendations $-108-$

List of references. $111-$

Appendices 121

Appendix A: Data collection timelines $121-$

Appendix B: Director General of School Administration, Innovation and Curriculum

Development (SAICD) $-122-$

Appendix C: Director General of SAICD's Consent Form. $125-$

Appendix D: School Principals Information sheet $127-$

Appendix F: School Principal's Consent Sheet as Participant $132-$

Appendix G: Teacher's Information Sheet. $134-$

Appendix H: Teacher's Consent Sheet $136-$

Appendix I: An example of exam text in Portuguese language $137-$

Appendix J: A student was retained had 43 band scores $138-$ 
Appendix L: An unclear student's work was given a score of 6 $140-$ Appendix N: An irrelevant exam question $142-$ 


\section{List of Tables}

Table 1: The Structure of Basic Education.............................................

Table 2: Basic Education Data in 2009 ............................................. -4-

Table 3: Repetition Rates in Elementary Education in 2008 ......................... -6-

Table 4: Distribution of participants by schools .................................. $-31-$

Table 5: Distribution of participants by position ................................ - $32-$

Table 6: Data collection tools .................................................. - $36-$

Table 7: Data collection timelines ............................................ $-37-$

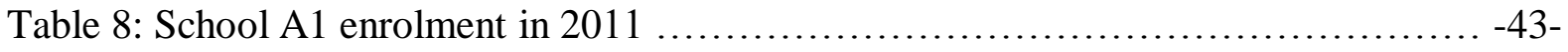

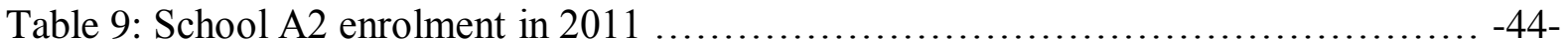

Table 10: School A3 enrolment in 2011 ........................................... -44-

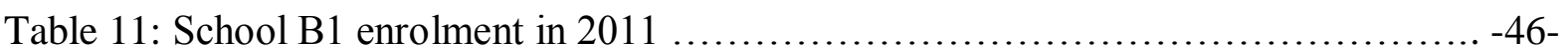

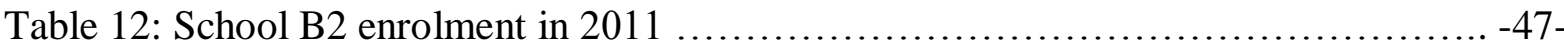

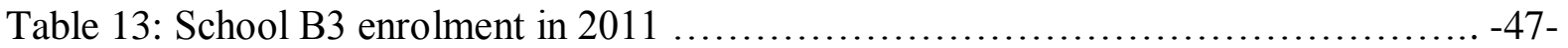

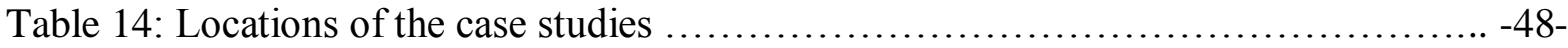

Table 15: Summary of school data in 2011 ....................................... -49-

Table 16: Backgrounds of the participants by case studies ......................... -50 -

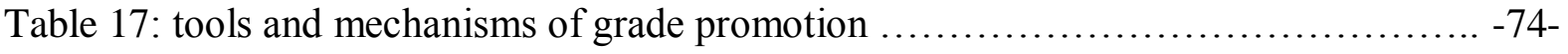

Table 18: Responses regarding formative assessments $\ldots \ldots \ldots \ldots \ldots \ldots \ldots \ldots \ldots \ldots \ldots \ldots, 75-$

Table 19: Responses regarding teachers interventions ............................ - $76-$

Table 20: Factors inhibiting students' learning ..................................... $-77-$

Table 21: Recommendations .................................................... 


\section{Chapter 1: Introduction}

\section{The context of the study}

The Democratic Republic of Timor-Leste, commonly known as East Timor, is a nation in Southeast Asia. It is a small country $\left(15,410 \mathrm{~km}^{2}\right)$ located about $640 \mathrm{~km}$ northwest of Darwin, Australia, with a population of approximately 1,066,582 in 2010 (Timor-Leste, 2012). Timor-Leste achieved its full Independence on 20 May 2002 after being colonised by the Portuguese for four centuries, Indonesia's illegal occupation for 24 years from 1975 to 1999 , and the United Nations Transitional Authority on East Timor from 1999 to 20 May 2002. The country's main land is located in the eastern part of the island of Timor. Timor-Leste is composed of 13 districts including an enclave that is located in west Timor.

\section{The education system}

\section{The development of education}

During Portugal's colonisation, the content and structure of the Timorese education system was shaped by Portuguese interest. The education system during this period focussed on educating a small administrative class that could manage the colony in Portugal's interest. Therefore access to education was limited to a small number of elite children (The World Bank, 2004). Consequently, by the end of Portugal's rule, in 1975, the illiteracy rate of the population remained high at about 90 percent (Saldanha, 1994, as cited in The World Bank, 2004). 
During the 24 years of Indonesian occupation, access to education for children of different economic and social background was largely increased, although the intent was to assimilate the Timorese generation into Indonesian society (Shah, 2011). By the end of Indonesian occupation the access to education was great. Gross Enrolment Ratio (GER) reached 94 percent, and Net Enrolment Ratio (NER) in primary education reached 74 percent and there was a primary school in every village in Timor-Leste. Despite having improved access to education, Timor-Leste's children's attainment was lower than that of Indonesia (World Bank, 2004).

After independence, the development of the education system needed to be shaped to fit the needs of the development of the country. The establishment of the education system in Timor-Leste therefore is based on the national constitution and conventions such as the Rights of the Child, and the Millennium Development Goal (MDG) and Education For All (EFA) goals (MoE, 2010a).

Taking into consideration each of these conventions, the development of education in TimorLeste in the initial years of its independence focussed on basic and secondary education.

The basic education system

The education system comprises pre-school, elementary, pre-secondary and secondary education. The pre-school programme is designed for 4-5 year old children, the elementary level is designed for 6-12 year old, the pre-secondary is for 13-15, and secondary level is for 16-18 year old children. 
The government combined the elementary and pre-secondary level and called it 'Nine Years of Basic Education'. As table 1 shows the Basic Education (BE) system is structured in three cycles. Cycles 1 and 2 cover six grades of primary education in which cycle 1 includes grades 1-4, and cycle 2 comprises grade 5-6. Cycle 3 involves three grades of junior secondary education grade 7-9 (Parlamento Nacional, 2008) .

Table 1: The structure of Basic Education

\begin{tabular}{|l|l|l|}
\hline Cycles & grades & Expected age \\
\hline Cycles 1 & Grades 1-4 & 6-12 year old \\
\hline Cycles 2 & Grades 5-6 & $13-15$ year old \\
\hline Cycles 3 & Grades 7-9 & $16-18$ year old \\
\hline
\end{tabular}

The Basic Education of Timor-Leste is organised through integrated basic education establishments in which there is a central basic education establishment and a number of nearby filial schools (primary schools) featuring first, second and third cycles (MoE, 2010b).

\section{The enrolment}

As table 2 shows, the number of pre-school students is far less than the number of elementary (cycles 1-2) students. This reflects that the priority in education is not given to pre-school but elementary school (Parlamento Nacional, 2008). The consequence of this policy is that most grade 1 students do not receive any formal pre-school education prior to their enrolment in grade 1 . Grade 1 therefore is students' first opportunity to experience formal education in a 
social environment other than home. Many children use their mother tongues at home while at school they face Tetun or Portuguese or both as the official languages of schooling.

Table 2: Basic Education data in 2009

\begin{tabular}{|l|l|l|l|}
\hline Type of schools & Schools & Students & Teachers \\
\hline Pre-School & 141 & 7,994 & 310 \\
\hline Basic Education (cycles1-2) & 1027 & 214,660 & 7,358 \\
\hline Basic Education (cycle 3) & 257 & 52,378 & 2,307 \\
\hline
\end{tabular}

(MoE, 2010a)

\section{The Academic Calendar}

In Timor-Leste, an academic year for basic and secondary education is split into three terms, each of which comprise one period of three months for teaching related activities and a one month school break which is used for teacher training (MoE, 2009).

The first terms begins in January and ends in the first week of April with an end of term test. The school break is for the three weeks and during this period teachers attend training. The second term starts soon after the teacher training and ends with the same activities as those of the first term. The third term starts in the first week of September.

Unlike the first and second terms, the third term ends with two important activities: the promotional examination for students in each grade, and the national examination for grade 9 
students. While the promotional examination aims at determining whether or not a student is promoted, the national examination aims at assessing year 9 students' learning outcomes in order to determine whether or not a student meets the national standard.

Those students who reach the standard are awarded a national certification of basic education completion, whereas those who fail are expected to repeat year 9 otherwise they cannot pursue a secondary education (MoE, 2010c).

\section{Challenges}

The establishment of the basic education system aimed to provide access to a quality primary education for all children residing in Timor-Leste (MoE, 2005). However, despite resources being allocated and a focus on achieving this goal, there remains high repetition rates and similarly high dropout rates (MoE, 2010a). As table 3 shows grade retention is higher in grade 1 than for grades in the subsequent years. In 2008 the grade repetition rate was at 30 percent in grade 1, falling to four percent in grade 6 (MoE, 2010a). This situation indicates that the internal efficiency of elementary education is very low due to the cost of high repetition and dropout rates, and this challenges the government expectation of access to education for all children who reside in Timor-Leste. 
Table 3: Repetition Rates in elementary education in 2008

\begin{tabular}{|l|l|l|l|l|l|l|}
\hline Grades & Grade1 & Grade 2 & Grade 3 & Grade 4 & Grade 5 & Grade 6 \\
\hline Repetition Rates & $30 \%$ & $22 \%$ & $18 \%$ & $15 \%$ & $12 \%$ & $4 \%$ \\
\hline
\end{tabular}

(MoE, 2010a).

\section{Rationale and aims of the study}

Grade retention is the practice of requiring a student who has been in a given grade level for a full school year to remain at that same grade level the following year (Jimerson, 2001; Owings \& Kaplan, 2001; Wynn, 2010). It has been a practice in primary education in TimorLeste since Indonesian occupation and even further back during Portuguese colonisation. Grade retention decisions in Timor-Leste are generally made at school levels by either class teachers alone or, in consultation with the school principal. There is research relating to the practice of grade retention with primary education students (Anderson, Jimerson, \& Whipple, 2005; Hong \& Yu, 2007; Jimerson, Ferguson, Whipple, Anderson, \& Dalton, 2002; Roderick \& Nagaoka, 2005; Witmer, Hoffman, \& Nottis, 2004), but none of this focuses on the TimorLeste context.

This study aims to investigate this practice and determine the rationale and criteria teachers apply to grade retention decisions in primary schools in Timor-Leste. It is envisaged that this study will provide valuable insights into teachers' beliefs about grade retention practices and their actions that serve to promote students or to retain them at the same year level. Thus, the main purpose of this study is to explore rationales behind the practice of grade retention in grade 1 of primary education in Timor-Leste. 
For this purpose, this study aims to:

(1) identify criteria and mechanisms grade 1 teachers employ to determine grade retention;

(2) investigate whether or not grade 1 teachers use formative assessment to plan intervention for those students at-risk of being retained;

(3) identify whether or not teachers act to intervene where students have been identified for retention;

(4) explore what teachers believe to be the barriers of student learning

(5) identify and describe grade 1 teachers' beliefs about grade retention;

\section{Research questions}

This study is guided by the following main questions: How do Timorese grade 1 teachers' beliefs influence their practice in grade retention?

Sub questions are:

(1) How do grade 1 teachers determine grade promotion-retention?

(2) What role do formative assessments have in students' learning prior to grade retention?

(3) What, if any, strategies do teachers use to improve students' learning in order to prevent them from grade retention?

(4) In relation to grade 1 retention what factors do grade 1 teachers believe inhibited students' achievement of learning outcomes?

(5) What beliefs do grade 1 teachers hold about grade retention practices? 


\section{Overview of the chapters}

This thesis is divided into six chapters. Chapter 1 has provided the context, the rationale for this investigation, and an outline of the research objectives.

\section{Chapter 2: Literature review}

This chapter reviews the literature which presents empirical evidence about grade retention and its effects on students' learning. Taking into consideration those factors involved in the practice of grade retention, the literature of this study encompasses teachers' beliefs, assessment for learning, moderation in assessments, classroom conditions, learning and motivation, and teaching intervention.

\section{Chapter 3: Research methodology}

This chapter explains the methodology in this qualitative case study. It describes how participants were selected, and data were collected and analysed in relation to the research question. This study also addresses the ethical considerations and limitations of this study.

\section{Chapter 4: Findings}

This chapter presents the findings about mechanism and criteria teacher used to determine grade retention in grade 1. It also presents the findings relating to how teachers used assessments for learning, and teaching interventions that can prevent at-risk students from being retained. Findings about factors that teachers believe inhibited students' learning, and teachers' beliefs about grade retention are also presented in this chapter. 
Chapter 5: Discussion of findings

This chapter discusses the findings, using academic evidence in the literature review to compare and contrast these findings. This chapter ends with a summary and conclusion.

\section{Chapter 6: Recommendations}

This chapter provides recommendations that can improve students' learning outcomes while reducing grade retention rates in primary education in Timor-Leste.

In the following chapter the researcher reviews the literature relating to grade retention in primary schools in Timor-Leste. 


\section{Chapter 2: Literature Review}

Grade retention in schools can be described as those mechanisms and procedures teachers use to retain a student. These involve teachers' beliefs about grade retention, assessment practices, classroom conditions, teaching interventions and the effect of grade retention for learning. The literature review to support this study therefore includes each of these areas. However it is important to note that to the researcher's knowledge there is no current literature regarding these practices in Timor-Leste. Therefore this study investigating grade retention will be the first of its kind and will address an important yet un-researched prevalent practice in TimorLeste schools.

\section{Grade retention}

Grade retention is the practice of requiring a student who has been in a given grade level for a full school year to remain at that same grade level the following year (Jimerson, 2001; Owings \& Kaplan, 2001; Wynn, 2010). Other researchers define grade retention as the practice of retaining students who have not fully mastered the curriculum or achieved a certain academic standard. The students are required to repeat the year while their peers are promoted to the next academic year (Ndarahutse, 2008). In contrast, "social promotion or automatic promotion is the act of allowing students to continue with the rest of their peer group despite not having meet the minimum required standards" (Ndarahutse, 2008, p. 9).

As defined by Ndarahutse, the most influential factor in the grade retention decision is the student's academic performance (Witmer et al., 2004). A study conducted in the Texas school 
district found student achievement was directly linked to the levels of grade retention (Bali, Anagnostopoulos, \& Robert, 2005).

The primary goal of these practices is to improve the students' knowledge and skills before she or he is promoted to the next grade level. Nason (1991) found the primary purpose of grade retention is to remediate academic difficulties or to prevent students' failure in later grades (Witmer et al., 2004). Another goal of grade retention is to give immature students a second chance to grow (Schnurr, Kundert, \& Nickerson, 2009). The perceived objectives are confirmed in another study (Geason, Kwok, \& Hughes, 2007) that found that the retained students' academic competence and peer relationships increased after being retained in the first grade. Schnurr et al., (2009) argue that based on the aforementioned objectives and short term positive effects, grade retention continues to be used as an intervention for struggling students.

Other evidence has shown that grade retention has been associated with various negative aspects of the retainees' learning (Anderson et al., 2005; Crissom \& Shepard, 1989; Guevremont, Roos, \& Brownell, 2007; Holmes, 2006; Hong \& Yu, 2007; Martin, 2011; Meisels \& Liaw, 1993; Roderick \& Nagaoka, 2005). They argue that grade retention has no positive effects on students' learning, and acknowledges that if there is a positive effect, it must be small and does not last long. These negative effects of grade retention include academic performance, lower self-concept and motivation to learn, and dropping out of school. 


\section{Academic performance}

Grade retention has been associated with academic failure of the students after being retained. Meisels and Liaw (1993) found that most of those who are retained a year, do not make a significant improvement in their learning after retention. Roderick and Nagaoka (2005) found students who were retained under Chicago's high stakes testing programme from 1997-2000 continued to struggle during their retained year. Similarly, Hong and Yu (2007) who studied specifically grade 1 retention found that the retainees' reading and math outcomes substantially fade by grade 5. Evidence from Canada shows only one in four third graders improved their scores after being retained (Guevremont et al., 2007).

\section{Lower self-concept and motivation to learn}

Grade retention has also been associated with lower self-concept and academic motivation (Martin, 2011; Nason, 1991). Anderson, Jimerson, and Whipple (2005) found grade 1, 3 and 6 primary students rated grade retention as the most stressful life. This rate is stronger than earlier evidence where primary students ranked grade retention as the most stressful life experience after going blind and losing a parent (Jimerson, 2004).

\section{Higher dropout rates}

Grade retention has been associated with the high probability of students dropping out of school after being retained (Alexander, Entwisle, \& Dauber, 2003). Grade retention in many cases appears to contribute to students' decision to leave school before graduation (Crissom \& Shepard, 1989). Further Crissom and Shepard (1989) found that students who dropped out 
repeated one or more grades in school. An example is quoted from the Association of Califormia Urban School Districts (1985), “in Los Angeles dropout had been retained more than five times than graduates" (Crissom \& Shepard, 1989, p. 36). In their co-relational study, Crissom \& Shepard (1989) conclude that holding back a student increases the dropout risk for the child, whereas Roderick (1995) calculated "one grade retention increased the risk of dropping out by 40 to 50 percent, and being two grades behind increased the risk by 90 percent" (Holmes, 2006, p. 58). Similarly, Guevremont et al., (2007) who examining data from Manitoba, Canada conclude that students who have been retained once have greater probability of dropping out of school three times higher, and almost eight times higher for those who have been retained more than once.

\section{Doubled education budget}

Grade retention has been associated with higher costs to education. Besides academic failure, school dropouts, and lower self concept of the student, the consequence of grade retention is the increase of educational expenditure (Alexander et al., 2003). The education annual budget is generally calculated based on the number of students and multiplied by an estimated cost per student in an academic year. For example, if the annual cost of a student is calculated as US $\$ 100.00$, this amount is multiplied by the number of students, for example 250,000 . The annual cost for the students will be 250 thousand $\mathrm{x} \$ 100=\mathrm{US} \$ 25$ million. The educational expenditure increases as there is grade retention (Alexander et al., 2003), if the figure above includes repeaters, for example 20 percent, this means 20 percent of the annual education budget, that is US\$5 million is shared by the repeaters. So, if there was no grade retention, 
the annual budget would not be US $\$ 25$ million but would be only US\$20 million. In a real history, the yearly cost of a primary education student in the United States in the 1980's was $\$ 4,051$. This means the annual US expenditure for education at that time increased an average of \$4,051 for each repeater (Centre for Policy Research in Education, 1990).

\section{Grade retention leads to defer students' chance to work}

Formal elementary and secondary education generally lasts around 12 or 13 years. It lasts 12 years in the Timor-Leste education system; students are officially enrolled in the first grade when they are six and they are expected to complete their secondary education level when they are 18 (Parlamento Nacional, 2008). Thus, the school leavers at this age can apply for a job. However, if they repeat one year during their elementary and secondary studies this leads to the possibility of deferring their chance to work until one year later, or if they do they work, they do so without a secondary diploma.

\section{Teacher beliefs}

Hattie (2009) contends that teachers are the most influential factor in children's academic learning. Therefore it is possible that their beliefs about their teaching practices and assessments will have an influence on student learning. Research has found that most grade retention decisions are based on the student's academic performance (Bali et al., 2005; Witmer et al., 2004). 
Teacher beliefs and perceptions about the benefit of grade retention have been found to influence decisions about retaining children with low academic performance (Witmer et al., 2004). This study relating to elementary teachers' beliefs and knowledge about grade retention, found that 77 percent of the participants believed that retention was an effective practice for preventing failure in the later grades (Witmer et al., 2004, p. 179). The most influential factor in decisions relating to retention of a student was academic performance, while effort, ability and social emotional needs of students were found to be the secondary influential factors for retention. Teachers were found to have limited knowledge about research findings of the effects of grade retention. Importantly, Witmer et al. (2004) concluded that the beliefs of elementary teachers leading to grade retention were not connected to research finding.

Schnurr, Kundert and Nickerson (2009) who examined grade retention decision making practices and school psychologists' knowledge, beliefs, and opinions regarding retention in the United States, found that retention rates are less in schools where school psychologists are involved in grade retention decisions, than those that do not employ school psychologists. Similarly, Larsen and Akmal (2007) found school principals who have knowledge on grade retention diminished numbers of students who were supposed to be retained because they knew the negative effects of grade retention on students. Despite having knowledge, the principals still retained some students, in order to please the policy makers and teachers who proposed the retention. 


\section{Assessments}

Assessment is an integral part of learning, teaching, schooling and education (Swaffield, 2008). Assessment practices have been influenced by different philosophical views of learning. Behaviourists define learning as acquisition of what is being taught (James, 2008). This point of view has influenced assessments that focus on students" "memorization of what has been taught" (James, 2008, pp. 21-24), whereas, cognitive constructivists regard learning as an active process of individual sense-making. Assessment, therefore, should go beyond recalling of facts to a deeper understanding and ability to apply conceptual framework to find solutions of problems (James, 2008). Social-culturalists view learning as an interaction between thought and actions in the context. Assessments resulting from this approach are internally carried out alongside the learning by the teachers, the peers and the students themselves with focus mainly by the use of resources in solving situated problems (James, 2008).

Assessment in relation to learning serves to fulfil two different purposes: assessment of learning (summative assessments) and assessment for learning (formative assessments). The main distinction between the purposes of assessments is their objectives that often refer to either assessment of learning, or assessment for learning (Swaffield, 2008). Assessment for learning aims to identify "students' existing ideas and skills, and recognising the point reached in development and necessary next steps to take (Harlen \& James, 1997). It is conducted alongside the learning process in which information about students' learning is gathered through observation, discussions with peers, talking to teachers, student work, 
student self-assessment and other products (Harlen \& James, 1997). Further, a formative assessment according to Hattie (2003) and Hattie and Timperley (2007) is considered essential if it is used as a means of providing feedback to students about their performance. In making use of assessment results for students' learning, Hattie (2003) recommends three feedback questions: “Where am I going? How am I going? and Where to next?” (p. 2).

Unlike assessment for learning, assessment of learning is conducted at the end of certain intervals, and it aims at reporting a bigger picture of students' learning achievement (Harlen \& James, 1997). By definition summative assessment differs from formative assessment. If the results of any assessments are used for improving students' learning outcomes, it is a formative assessment (Harlen, 2005). Harlen in his argument suggested an optimum use of assessment data for students' learning. This aligned with Hattie's (2005) preposition regarding assessment data that should be conceived as not something about the students themselves but about the teacher. In short, students' achievement should also be regarded as teacher's teaching, because children fail to achieve the academic expectation is the failure of the adult to create a conductive learning environment (Jimerson, 2004). Evidence of this (Hattie, 2005; Jimerson, 2004) suggest teachers plan for their teaching based on assessment data of students' learning. The teachers may change their teaching approach if assessment data shows any negative learning outcomes of their students. 


\section{Assessment in Timor-Leste}

In the Timor-Leste primary school context, assessment as described above (Harlen, 2005; Harlen \& James, 1997; Hattie, 2005; Jimerson, 2004) is comprehensively provided in the curriculum implementation plan for primary education (MoE, 2006). In this document assessment types, with emphasis on formative and summative assessment, are clearly described in order to guide teachers while implementing the new primary education curriculum introduced in 2005. The key points of the formative assessment according to MoE (2006) provide teacher, students, parents and other education stakeholders with information regarding the learning progresses in a way that allows revision and to improve the processes of the work. Further, it emphasises that assessment for learning is not merely to assess the students' learning but to use the students' performance to evaluate the adequacy and the effectiveness of teaching. This underlines the idea that 'if the student did not learn, it was because the teaching was not adequately performed' (MoE, 2006, p. 44). Furthermore, two recent research projects conducted in Timor-Leste relating to Timorese teaching in the classroom, found some concerns about Timorese teaching (Quinn, 2011). In her research about the language of schooling in Timor-Leste, Quinn (2011) found that Timorese teachers dominated the talk in the class and students were given about ten minutes at the end of each lesson to respond to questions that only required yes or no answers. Another researcher (Shah, 2011) investigated teachers' perceptions, practices and policy in Timor-Leste and found that after teaching, teachers did not move around the class while students were working, instead, they sat on their desk in front of the class. 


\section{Moderation}

Moderation is "a form of quality assurance for delivering comparability in evidence-based judgments of student achievement" (Maxwell, 2007, p. 2). A more specific term for moderation is quality control, and refers to efforts in ensuring assessment procedures and outcomes are consistent. This implies that assessment procedures and outcomes are checked based on common characteristics or criteria (common standards), such as syllabuses or other frames of reference before they are reported (Maxwell, 2007). By doing so it aims to ensure that all achievement is given the same grade or level of achievement having reached the same standard.

A study of standards in moderation that focuses on how teachers of years 4-9 use stated standards in moderation to achieve consistency in judgment suggests that even with stated standards, judgments results differed amongst the teachers (Wyatt-Smith, Klenowski, \& Gunn, 2010). This variance of teacher individual judgments occurred due to each individual interpretation of the stated standards (Wyatt-Smith et al., 2010). Teachers' bias of judgments is generally due to their consideration of non-relevant aspects of student behaviour (Harlen, 2005).

"Teacher based-assessment is usually deemed to have high validity but questionable reliability" (Klenowski \& Wyatt, 2010, p. 115). Thus moderation is essential to reach consistency and reliability of the assessment results. 


\section{Class size impact}

Class sizes are defined based on the number of students in a classroom as large (30 and over), large medium (26 to 29), small medium (21 to 25), and small (20 or less) (Blatchford, Bassett, Goldstein, \& Martin, 2003). Some other researchers defined class sizes as only small or large. Folmer-Annevelink, Doolaard, Mascareño, and Bosker (2010) considered a small class size if it consists of less than 20 students and a large class is not precisely defined but if it consists 22 students or larger.

A longitudinal study with a multi-method research approach conducted in the United Kingdom of over 10,000 students from school entry through the infant stage, aimed at finding out whether class size differences affect students' learning achievements. This study found that the effect on different class sizes on student's learning achievement were obvious. The lowest achiever in literacy on entry to school benefitted most from smaller classes, particularly with class size under 25 (Blatchford et al., 2003). This finding aligned with other findings of this study that in small class sizes, there was more often teacher-student interaction. Teachers had more opportunities to interact with individual students in order to facilitate individual learning. Conversely in the large class sizes there were more groups or larger sizes of groups that limited opportunities for teachers to facilitate group or individual learning of the students. A similar study was conducted in Kindergarten and grade one classes from 46 Dutch primary schools which addressed the effect of class size and the amount and type of student-teacher interaction. This study found that smaller class size related more to student-teacher interaction (Folmer-Annevelink et al., 2010). The academic 
studies aforementioned revealed the effect of class sizes on students' learning achievements through both teachers and students.

\section{The effect of class size on teachers}

There was a consistent relationship between class sizes and teaching in general, particularly on teaching time. There was correlation between the size of class and teaching time. In other words there was a correlation between the size of class and non-teaching time. In small class sizes there was more teaching overall than in the larger ones The larger the class size the more non-teaching time (Blatchford et al., 2003, p. 716). Further, results from the quantitative methods of this study indicate that students in larger classes interacted with their teacher less than those in small class sizes. In a small class students were observed 213 times as compared to 144 times in a large class size. In line with this finding, Folmer-Annevelink, et al., (2010) found interaction between teacher and students in small classes was significant, meaning that interaction between teachers and students were high.

\section{The effect of class size on students}

Blatchford, et al. (2003) also studied students' behaviour and peer relations in which they found that in small classes, students did not merely receive interaction from their teachers but more actively took initiatives. This was not the case in large class sizes. Students in large class sizes were less proactive in interaction with their teachers (Blatchford et al., 2003, p. 718). In addition the evidence of this study showed that students in the small class size were more actively engaged in the learning process than those in the larger class size. Pupils in the 
small class size were more attentive than those in the larger class size. On the contrary, students in the larger class size could hardly concentrate to the learning process (2003, p. 719).

Taking into consideration the benefit of learning in small classes, countries around the world, including the United States of America, have launched class size reform. In the USA class size reform has been implemented in 40 states. Class sizes have been reduced to 15:1 or 30:2 (Graue, Rauscher, \& Sherfinski, 2009).

Despite the benefits for effective learning, small class sizes without a quality classroom cannot produce quality learning outcomes for the students. The quality of classrooms includes structure quality, teacher quality, process quality, and instructional and emotional supports (Graue et al., 2009). This study addressed how class size reduction and classroom quality interaction produce learning opportunities in elementary classrooms. The researcher found that the same class size 15:1 did not produce the same learning opportunities that would potentially produce different learning outcomes. This finding reveals that classroom quality and teacher quality are equally important to make students' learning achievement effective.

\section{Learning and motivation}

Learning and motivation are linked (Alderman, 1999). Research shows that there is a strong link between classroom practice and students motivation to learn (Alderman, 1999). Motivation is an internal state that pushes, directs and maintains behaviour (McInerney \& 
McInerney, 2006) and motivation of learning is defined as students' energy to learn and work effectively and achieve their potential at school (McInerney \& McInerney, 2006). Illeris (2009) defines learning "as any process that a living organism leads to permanent capacity change which is not solely due to biological maturation or ages". He further explains that learning begins with the interaction between the individual and the environment. The result of learning differs depending on the learning possibility that is influenced by the learning condition. This learning theory aligns with Vygotsky's Zone of Proximal Development (ZPD) that children based on their actual development can independently reach certain levels of leaning outcomes, but they can learn better than that under adult guidance or peers, and or, with mediating artefacts (Vygotsky, 1978). The process of helping children to reach better learning in such a way was later termed 'scaffolding' by Jerome Bruner (Bee \& Boyd, 2007).

Motivation, according to Illeris (2009) is the incentive dimension of learning which comprises such psychological elements as feeling, emotion, motivation and volition. Incentive is the mental force that runs the process of making meaning of the input, but it is always influenced by the content, whether it is an interest, a necessity or a compulsion (Illeris, 2009). In line with Illeris, different theorists present their discussions and beliefs about learning motivation: Heron (1992) states that learning involves interests or needs. If there is no need, there is no deed. Conversely, if there is no such incentive, there is no reason to drive the learning (Illeris, 2009). Similarly, Dweck and Master (2008) believe that learning would not be effectively achieved if there is no effort and motivation, even if one had ability. Ziehe (2009), in his discourse of youth learning, argues that youth are highly motivated in learning 
what it is to demonstrate a "will". Ziehe believes that youth prefer learning what they want and not what others want them to learn. Students with low competency of motivation demonstrated low engagement in the classroom (Hudley \& Gottfried, 2008).

Another factor that contributes to incentive is the experience. Pre-existing knowledge can help the learner to gain new knowledge by assimilating the two. In line with this, Usher (2009) discusses that "experience can provide new and useful insight into a wide range of issues and problems and can clearly be used to access, supplement, complement, critique and challenge understanding of the world derived from disciplinary knowledge" (Illeris, 2009, p. 181). Similarly, Engestrom (1987) states that people will be encouraged by their experiences to explore ways to solve difficulties. Engestrom (1987) also points toward the learning products and states that motivation can stem from having something useful to produce. Finally, he suggests that motivation can stem from a working situation where everyone values the participation in collaborative practices; habits of the community.

Illeris (2009) believes motivation is always influenced by the contents (p.10). Children's motivation in learning can stem from the content that is useful to produce (Engestrom, 1987) or if children perceive the content of the learning as an interest or need (Heron, 1992).

Children do not arrive at school without knowledge; their ideas are formed by their differing socio-economic, cultural backgrounds and language (Gardner, 2009; McInerney \& McInerney, 2006). Therefore they have different styles of learning, and need different 
approaches to cope with their individual styles of learning (Gardner, 2009). Most importantly, children are encouraged in learning by addressing their barriers to learning, such as problematic frames of reference" (Mezirow, 1978), defence mechanism, and mental resistance (Illeris, 2009). Students with such problems require a conducive and supportive environment to motivate their learning because motivation can stem from participation in culturally-valued collaborative practices (Engestrom, 1987). When discussing environmental factors that influence learning, social cognitive theorists believe that there is an interrelation between an individual's cognitive process (i.e beliefs and ability) and behaviour or performance and the social environment (Bandura, 1989). The environmental factors such as classroom behaviours, incentives and evaluation criteria, influence the behaviour or performance of learners (Alderman, 1999).

\section{Intrinsic motivation}

Intrinsic motivation, is "as the doing of an activity for its inherent satisfactions rather than for some separable consequence" (Ryan \& Deci, 2000, p. 56). It is facilitated through tasks that the learner perceives as interesting and personally relevant and meaningful, appropriate in complexity and difficulty to the learner's abilities and on which they believe they can succeed. Intrinsic motivation involves the feeling of satisfaction of doing an activity (Ryan \& Deci, 2000); valuing of the activity for its own sake (Heckhausen, 1991); it is the joyous absorption in the activity which characterises a truly motivated person (Nakamura \& Csikszentmimalyi, 1989). However, extrinsic motivation is a "construct that pertains whenever an activity is done to attain some separable outcome” (Ryan \& Deci, 2000). 


\section{Extrinsic motivation}

In certain circumstances extrinsic motivation can be detrimental to motivation and performance, i. e. children are given an extreme task with a gift. Some children will not make an effort if they believe they cannot do the task (McInerney \& McInerney, 2006). An extremely difficult task does not encourage children to make an effort in order to get the job done, especially if they believe that they cannot get the job successfully done. Similarly, a reward for children to get a task done is encouraging. However, children may subsequently expect constant rewards for their jobs, and they will not do the job properly if they think they will not receive a reward. This rewarding can negatively affect continuing motivation of children (Deci, Koestner \& Ryan (2001). In contrast to this finding, Cameroon and Pierce $(1994,1996)$ believe that "in settings such as classrooms verbal rewards (praise and positive feedback) can be used to enhance intrinsic motivation". These authors also believe that rewards can be given for work completed, for solving problems successfully, or for maintaining a predetermined level of performance without undermining intrinsic motivation. However, McInerney and McInerney (2006) have stated that if a reward is given without regard to the level of performance, students could diminish continuing motivation in the task when rewards are withdrawn (McInerney \& McInerney, 2006).

Extrinsic rewards such as stamps and stars can enhance motivation and promote learning, especially in the tasks that children have little interest (McInerney \& McInerney, 2006). Once children have some level of progress, they do not really require further reinforcement. Appropriate rewards for young children might be, for example, small presents, free time, 
teacher praise, house points, stars, certificate, a letter to parents and child saying how well the child has done (McInerney \& McInerney, 2006). Children that do not receive rewards within such a system can lead to a reduction in their sense of competence and a subsequent loss of interest in the task (McInerney \& McInerney, 2006).

\section{Teaching intervention}

Students are generally retained due to their academic failure, although their academic achievements are not determined only by the students themselves but also due to different factors such as classroom conditions, curriculum and learning materials, and teacher qualifications. Illeris (2009) believes the result of learning depends on the capacity of the environment from which the learners have interaction. Thus, poor environment is likely to produce poor learning outcomes. On the contrary a conductive environment can produce better learning outcomes. In his meta-analysis, Jimerson (2004), examining the efficacy of grade retention, concludes that the failure of children in kindergarten, grades 1,2 , and 3 are not their own fault. These children fail to achieve academic expectation due to the failure of adults to provide appropriate learning environments that contribute to their learning. Jimerson (2004) suggests early intervention strategies to prevent academic failure of at-risk students rather than grade retention. He recommends reading intervention, behaviour modification, cognitive training, direct instruction, and parental involvement. Other researchers (Temple, Reynolds, \& Ou, 2004) suggest additional instruction, tutoring, home-school partnerships, and tackle motivations, targeting literacy, and numeracy. 
Regarding the prevention of academic failure and addressing behavioural problems, Jimerson (2006) suggests school-wide intervention and classroom teaching intervention. School-wide intervention involves the school management effectively supporting learning, whereas classroom intervention involves the capacity of the teacher to manage and facilitate learning. These include a (1) pre-school programme, (2) comprehensive school-wide programme (3) summer school and after school programme, (4) parental involvement, and (5) early reading programme.

\section{Pre-school programme}

The basic purpose of preschool intervention is to prepare young children of poor social and economic background for future academic success through enhancing foundation skills (Ziggler \& Styfco, 2000). A high quality preschool programme increases at-risk students' academic performance, reduces grade retention and dropout rates. Evidence in preschool programmes offered by Chicago Child-Parent Centres revealed the probability of students dropping out in high school were reduced by 7 or 8 percentage points (Temple, Reynolds, \& Miedel, 1998).

\section{Summer school and after school programme}

Summer school programmes focus on providing instruction during the school breaks, whereas after school programmes provide supplementary support outside of the normal school days and hours (Jimerson et al., 2006). Giving students additional instruction after school or in summer school may reduce the risk of students dropping out as they are not held 
back (Temple et al., 1998). Other evidence (Denton, Solari, Ciancio, Hecht, \& Swank, 2010) shows kindergarten students gain significant reading and listening comprehension improvement in summer reading programmes. More specifically, Vollutino, Scalon, and Tanzman (1998), who studied grade 1 students, found that one-on-one tutoring for 30 minutes per day for 1-2 semesters improved reading skills in students (Denton et al., 2010). This programme has greatly reduced the number of disabled readers (Bramlett, Cates, Savia, \& Lauinger, 2009). Similarly, O’ Connor and Simic (2002) who studied the effect of daily reading recovery programmes that last for 30 minutes per day for 12-20 weeks, as cited in Bramlett at al., 2009, reported a 5 percent reduction in estimated referral rates and a 3 percent decrease in special education placement rates.

\section{Summary}

As this review of literature shows, international studies have identified a range of factors that relate to decisions made about grade retention. These include teachers' beliefs, the use of assessment, moderation, class sizes, learning and motivation, and teaching intervention.

The following chapter describes the research methodology used in this research. 


\section{Chapter 3: Research methodology}

The philosophical framework that guides this study is social-constructivist. Socialconstructivists believe that the nature of the social world might vary between different cultures and different groups (Denscombe, 2010). They perceive that people construct meaning by interpreting their experiences in life in the world and develop subjective meanings of their experiences towards certain objects or things (Creswell, 2009). In this view, meanings are constructed as people engage in the world and these meanings are based on experiences and culture (Creswell, 2009; Denscombe, 2010). The theory is relevant to this study as it aimed to investigate the rationales behind grade retention. The rationales referred to are those of individual subjective teachers.

The study used a qualitative approach, as it is the most suitable paradigm to address the research questions, because teacher beliefs may be consciously or unconsciously held (Pajares, 1992). Collecting data regarding beliefs and their practice can be very difficult as teachers' stated beliefs are not always consistent with their behaviour (Jorgensen, Grootenboer, Niesche, \& Lerman, 2010).

Among various types of qualitative research, case study is best suited to the purpose of this study. Case study is a research methodology that allows the researcher to collect holistic explorations, descriptions and explanations about a case (Berg, 2004; Yin, 2003). Johnson and Christensen (2008) define this as "research that provides a detailed account and analysis 
of one or more cases"(p. 406). Therefore case study is an appropriate methodology to describe the teachers' beliefs and practices in relation to grade retention. A collective case study design will be more appropriate to this study as the researcher seeks to compare grade 1 teachers' beliefs and practices in relation to grade retention from different schools in different districts in Timor-Leste.

\section{Characteristics of the participants}

The key participants of this study are six Timor-Leste primary teachers, two of whom are teaching principals. The six key participants have taught for at least four years in Grade 1 . As table 4 shows, the participants were selected from two different districts, with three teachers from each. The teachers were working under three different schools structures: one in the main town; one in a sub-district town; and another in a village.

Table 4: Distribution of participants by school

\begin{tabular}{|l|l|l|l|l|}
\hline Districts & District town & Sub-district town & Village & Total \\
\hline District A & 1 & 1 & 1 & 3 \\
\hline District B & 1 & 1 & 1 & 3 \\
\hline Total & 2 & 2 & 2 & 6 \\
\hline
\end{tabular}

As table 5 shows principals were also selected to cross-check data and to provide information about policy and administrative areas of the school. The principals were also interviewed for questions four and five, whereas, teaching principals were interviewed under the role of a teacher. 
Table 5: Distribution of participants by position

\begin{tabular}{|l|l|l|l|}
\hline Participants & Teachers & Teaching principals & Principals \\
\hline District A & 2 & 1 & 2 \\
\hline District B & 2 & 1 & 2 \\
\hline Total & 4 & 2 & 4 \\
\hline
\end{tabular}

Criteria for selection of these two districts were their variation in context and the government's structure with the schools in district towns. Schools in district towns have better access to educational services than those in sub-districts towns which, in turn, have better educational access than those in villages. This is due to the structure of the government services which concentrate in the district main towns after Dili, the capital. In addition the choice of the two districts was based on their diverse context.

\section{Conflict of interest}

There was potential conflict of interest with the researcher having previously held a position of authority as the Deputy Director General in the Ministry of Education, Timor-Leste. As Patton (2002) noted it was important that the researcher remain neutral which included ensuring there was no imbalance in the perceived power relationship between researcher and participant. As the researcher no longer holds this position in the Ministry of Education (MoE) it was possible to explain this to participants to assure them that he no longer held that position, and was a student. He also made sure they understood that everything they told him 
would be remain confidential and their identity would not be revealed. To this end, each participant was assigned a pseudonym.

\section{Participant selection}

To begin data collection, the researcher met with the General Director of Education who oversees curriculum and assessment at the Ministry of Education (MoE) in Dili to seek authorisation for this study. An explanation letter was presented to the General Director (Appendix B), and the consent form was signed for this study (Appendix C). All letters and interviews were conducted in Tetun and translated to English by the researcher, who - like the participants - speaks Tetun as his second language.

The next step was the selection of districts.

\section{The selection of districts}

The choice of districts was purposive to consider different contexts. Therefore one district was selected from the central region and the other was from the western region. The central region comprises districts in which people speak the most widely spoken mother tongue in the country, whereas the west regions are more diverse in terms of ethnic language population.

Based on this rationale, the researcher selected District A from the central region, and District B from the west region by a phone call to the education superintendents. Their agreement for 
this study allowed the researcher to make forward steps of visiting the district education superintendents.

After making this decision, the researcher travelled to District A to meet and present the explanation letter to the education superintendent for this study. The superintendent allowed the researcher to visit the school A1 which is located in the main town, and to select one of the district's five sub-districts for schools A2 and A3

The selection of sub-districts and villages

The choice of sub-districts and villages took into consideration accessibility to the researcher as the road conditions are poor and can become dangerous, particularly in the rainy season. Thus the choice of sub-districts and villages were a purposive selection. The subsequent steps involved meeting the principals and the teachers.

\section{The selection of principals}

Following the choice of districts, and its sub-district and village, the researcher made an appointment with the principals by visiting the school. A letter of explanation (Appendix D) was presented to each of the principals, to whom the consent forms were sought, one of which was the consent form as principal (Appendix E) and another was the consent form as the participant of this study (Appendix F). 


\section{The selection of teachers}

The teachers who had been assigned a grade 1 class were approached to seek consent. A letter of explanation of this study (Appendix G) was presented to the grade 1 teachers to seek their consent. After reading the letter and listening to the researcher, in some schools, more than one grade 1 teacher expressed willingness to take part in this study. They could all speak Tetun but the researcher selected one who has been teaching for over four years. The consent form was given to the selected teacher (Appendix $\mathrm{H}$ ). The same procedure for selecting participants from district A was applied for district B. The following step was data collection.

\section{Data collection}

\section{Methods}

In this study, data were collected using semi-structured interviews and school documents relating to grade retention. Each teacher was interviewed in Tetun, the language in which they feel most comfortable, a voice recording was made and transcribed, and notes were taken with the consent of the teachers.

Tools

Data relating to grade retention practices were collected by using the research tools as shown in table 6. 
Table 6: Data collection tools

\begin{tabular}{|l|l|l|}
\hline Key Questions & Research Tool & Key Personnel \\
\hline $\begin{array}{l}\text { How do grade 1 teachers determine } \\
\text { grade promotion or retention? }\end{array}$ & $\begin{array}{l}\text { Interview with open ended and } \\
\text { close ended questions, and study } \\
\text { school documents }\end{array}$ & $\begin{array}{l}\text { Teachers and } \\
\text { principals }\end{array}$ \\
\hline $\begin{array}{l}\text { What role does formative } \\
\text { assessment have in students' } \\
\text { learning prior to grade retention? }\end{array}$ & $\begin{array}{l}\text { Interview with open ended } \\
\text { questions and study school } \\
\text { documents }\end{array}$ & Teachers \\
\hline $\begin{array}{l}\text { What, if any, strategies do teachers } \\
\text { use to improve students' learning in } \\
\text { order to prevent them from being } \\
\text { retained? }\end{array}$ & $\begin{array}{l}\text { Interview with open ended } \\
\text { questions }\end{array}$ & Teachers \\
\hline $\begin{array}{l}\text { What factors do grade 1 teachers } \\
\text { believe inhibit students' } \\
\text { achievement of learning outcomes? }\end{array}$ & $\begin{array}{l}\text { Interview with open ended and } \\
\text { close ended questions }\end{array}$ & $\begin{array}{l}\text { Teachers and } \\
\text { principals }\end{array}$ \\
\hline $\begin{array}{l}\text { What beliefs do grade 1 teachers } \\
\text { hold about grade retention practices? }\end{array}$ & $\begin{array}{l}\text { Interview with open ended and } \\
\text { close ended questions }\end{array}$ & $\begin{array}{l}\text { Teachers and } \\
\text { principals }\end{array}$ \\
\hline
\end{tabular}

\section{Timelines}

As table 7 shows, data collection was conducted in Timor-Leste from the second week of November 2011 until the second week of January 2012. 
Table 7: Data collection timeline

\begin{tabular}{|c|c|c|c|c|c|c|c|c|c|c|c|c|}
\hline \multirow[t]{2}{*}{ Steps } & \multirow[t]{2}{*}{ Data collection activities } & \multicolumn{3}{|c|}{ Nov.2011 } & \multicolumn{4}{|c|}{ Dec. 2011} & \multicolumn{4}{|c|}{ Jan 2012} \\
\hline & & II & III & IV & I & II & III & IV & I & II & III & IV \\
\hline 1 & $\begin{array}{l}\text { Received ethical approval from VUW } \\
\text { Human Ethics Committee }\end{array}$ & & & & & & & & & & & \\
\hline 2 & Travelled to Timor-Leste & & & & & & & & & & & \\
\hline 3 & $\begin{array}{l}\text { Visited and approached Minister/ Directors } \\
\text { of Ministry of Education of Timor-Leste, } \\
\text { and selected the participants }\end{array}$ & & & & & & & & & & & \\
\hline 4 & $\begin{array}{l}\text { Interviews conducted and documents } \\
\text { studied, interviews transcribed, transcription } \\
\text { checked, and translated from Tetun into } \\
\text { English }\end{array}$ & & & & & & & & & & & \\
\hline 5 & Travelled back to New Zealand & & & & & & & & & & & \\
\hline
\end{tabular}

\section{Type of data to be analysed}

This study collected mainly qualitative data, however some quantitative data including number of grade 1 repeaters boys, girls, and, the numerical marks given to students' learning were also collected. Quantitative data included the number of grade 1 repeater boys and girls. This data used to compare grade retention rates amongst grades within a school as well as across districts. Numerical scores assigned by teachers were used to determine what criteria are applied. This is particularly important as different teachers gave different scores to the same criteria across schools in different districts. The sources for gaining information about grade retention related practices were teachers, school principals and school documents such as those related to enrolment, lists of repeaters and, student summative reports. 


\section{Data analysis}

Data were analysed using procedures indicated by Johnson and Christensen (2008):

1) Segmenting: dividing data into meaningful analytical units;

2) Descriptive coding: making segments of data with descriptive words

3) Categorisation of codes: grouping descriptive codes

The key codes related to the themes that have emerged from the literature review, mainly grade retention, teacher's beliefs, teaching interventions and assessments. Sub-categories of codes were developed as data were analysed.

\section{Reliability}

In qualitative research, reliability refers to the extent to which researchers' approaches are consistent across different researchers and different projects (Gibbs, 2007). For this purpose, qualitative researchers need to document all the procedures of their case study (Yin, 2003). In this study, several steps were taken to ensure the consistency of the research findings.

First, interviews were recorded with careful note taking made of any relevant information in written documents. Second, the recorded interviews were played multiple times before they were transcribed in their original language. Third, transcripts, and the translation of transcripts were checked by the researcher to make sure that there were no mistakes made during transcription and translation to English. A summary of each interview was given back and checked by the participants to ensure the researcher correctly understood the content in the interview. 


\section{Validity}

In qualitative research, validity refers to the accuracy and credibility of the research (Creswell, 2009). According to Johnson and Christensen (2008), this also means the research is plausible and trustworthy. The following strategies were employed to make sure the study was valid. First, verbal responses to interviews and school documentations were used to gain deeper understanding and to ensure participants' perceptions were interpreted accurately. Second, the transcribed interviews were sent to participants to verify their accuracy.

\section{Ethical considerations}

This study was conducted following the Victoria University of Wellington Human Research Ethics Regulations and New Zealand Association for Research in Education ethical guideline (NZARE, 2010). The Human Ethics application was approved by the Faculty of Education's Ethics Committee. In Timor-Leste, there are no specific ethical guidelines to follow. However, the Ministry of Education of Timor-Leste was informed, and permission was sought and granted to conduct the research.

Participants were fully informed about research procedures, and consent was obtained before data collection took place. The identities of participants have been protected at all the stages, and any information about the participants acquired during the research process have been kept confidential to ensure that their professional integrity is not compromised by anything they contributed to the study. 


\section{Summary}

As described, this chapter outlines the processes employed for the collection of data. It presents the theoretical framework that guides this research, the selection of participants, the ethical approach to the participants, data collection tools and methods, and procedures the researcher used to ensure the validity and reliability of the research.

In the following chapter the researcher presents the findings of this study. 


\section{Chapter 4: Findings}

\section{Introduction}

This chapter will present the findings of the semi-structured interviews that were conducted with six teachers, two of whom were teaching principals and the other four were principals in two districts of Timor-Leste over a period of two months.

Participants' responses to the semi-structured interviews are presented under each question. Questions one, two and three are responses from the teachers and teaching participants $(\mathrm{N}=6)$ only, whereas questions four and five are responses from all participants including the teachers, the teaching principals and the principals $(\mathrm{N}=10)$. Additionally, school documents relating to grade retention such as student reports, written exams, list of students, school data and student's marked exams were requested and analysed to triangulate data sources. Analyses of these documents follow the reporting and analyses of the interviews.

\section{Case studies}

The schools were grouped based on their districts into two case studies, both of which comprise three schools, and each school is represented by a grade 1 teacher and his or her principals. Case study one involved three school participants from district A, and case study two covered three school participants from district B. Each school context is briefly described to provide key ideas about the students' enrolment and their family background. 
The context

The data were collected from six schools in six different localities in two districts. The two districts are coded district $\mathrm{A}$ and district $\mathrm{B}$. The choices of these two districts were based on their contexts. District A is one of the districts in which most people live on plantations. District B is one of the districts in which income is derived mostly from crop farming.

\section{The context of schools in case study one}

Case study one comprises the three school participants of district A which are coded as schools A1, A2, and A3. Each of these schools is surrounded by plantations from which the income of the population is produced.

\section{School A1}

This school covers grades 1-6 of Basic Education. It is located in the main town of district A. In 2011, 1193 students were enrolled. The principal reported that 82 of the enrolled students had left school before the end of the year. In all, 88 pupils from across all grades failed at the end of year exams.

Grade 1 students are evenly divided into four classrooms, each of which is taught by an individual teacher. The research focused on only one teacher. In school A1 the teacher has been given a pseudonym Celina. As table 8 shows Celina taught 58 students, 24 of whom moved to a new school at mid-year. Seven of the remaining students were not promoted to 
grade two, in addition to four who left the school before the end of the year. All students speak Tetun and their mother tongues. Most parents are farmers of plantations. The school is staffed with 37 teachers including seven volunteers.

Table 8: School A1 enrolment in 2011

\begin{tabular}{|l|l|l|l|l|l|l|l|l|l|l|}
\hline \multirow{2}{*}{ Grades } & \multicolumn{4}{|l|}{ All students } & \multicolumn{2}{l|}{ 'Dropped out' } & \multicolumn{2}{l|}{ Failed exam } \\
\cline { 2 - 10 } & M & F & Total & M & F & total & M & F & total \\
\hline All grades & 639 & 559 & 1198 & NR & NR & 82 & 64 & 24 & 88 \\
\hline All grade 1 (4 rooms) & 128 & 98 & $\mathbf{2 2 6}$ & 12 & 12 & $\mathbf{2 4}$ & NR & NR & NR \\
Celina's room & 34 & 24 & $\mathbf{3 4}(\mathbf{5 8})$ & NR & NR & $\mathbf{4}$ & 7 & 0 & 7 \\
\hline
\end{tabular}

Note: $\mathrm{NR}=$ No Reports

\section{School A2}

School A2 is located in one of district A's sub-district towns in which most parents are traditional plantation farmers. Students in this school are also bilingual, Tetun and their own mother tongue. The school is staffed with 15 teachers including five volunteers. As table 9 shows, school A2 offers education for grades 1-6 of Basic Education and had 302 students in 2011. The school principal reported that 31 students from different grades were retained at the final exams at the end of the year. However, this was not the case in grade 1 where all students who attended the final exams were promoted. 
Table 9: The school A2 enrolment in 2011

\begin{tabular}{|l|l|l|l|l|l|l|l|l|l|l|}
\hline \multirow{2}{*}{ Grades } & \multicolumn{3}{|l|}{ All students } & \multicolumn{3}{l|}{ 'Dropped out' } & \multicolumn{3}{l|}{ Failed exam } \\
\cline { 2 - 11 } & M & F & Total & M & F & total & M & F & total \\
\hline All grades 1-6 & 156 & 146 & 302 & 2 & 3 & 5 & 18 & 13 & 31 \\
\hline Grade 1 only & 22 & 25 & $\mathbf{4 7}$ & 0 & 1 & $\mathbf{1}$ & 0 & 0 & 0 \\
\hline
\end{tabular}

\section{School A3}

School A3 is located in a village under the sub-district where school A2 is located. Most parents are mainly farmers of plantations. Students in this school also spoke Tetun beside their mother tongues. The school is staffed with 21 teachers including eight volunteers. As table 10 shows, this school also covered grades 1-6 of Basic Education. School data showed 346 children enrolled in 2011. However, the principal reported that 43 pupils were not promoted to the higher grades at the end of 2011 exams. The school data also shows that there were 90 grade 1 students enrolled in 2011. This number of grade 1 students was further grouped into two classrooms. There was no information about the retention practices in one classroom. However, ten students from the participating teacher's classroom were reported to have been retained at the end of year exams in addition to five who left school earlier.

Table 10: The school A3 enrolment in 2011

\begin{tabular}{|l|l|l|l|l|l|l|l|l|l|}
\hline \multirow{2}{*}{ Grades } & \multicolumn{4}{|l|}{ All students } & \multicolumn{2}{l|}{ 'Dropped out' } & \multicolumn{2}{l|}{ Failed exam } \\
\cline { 2 - 11 } & M & F & total & M & F & total & M & F & total \\
\hline All grades & 191 & 155 & 346 & NR & NR & NR & 30 & 13 & 43 \\
\hline All grade 1 (2rooms) & 46 & 44 & $\mathbf{9 0}$ & 9 & 5 & $\mathbf{1 4}$ & NR & NR & NR \\
Mariana's room & 18 & 22 & $\mathbf{4 0}$ & 2 & 3 & $\mathbf{5}$ & 5 & 5 & 10 \\
\hline
\end{tabular}

Notes: NR = No Report. 


\section{The context of schools in case study two}

Case study two comprised three school participants of district B which are coded as school B1, B2, and B3. The land of these three schools is considered dry (less fertile), but despite this, the population's income is mainly derived from crops.

\section{School B1}

School B1 is located in the main town of district B. It is a centre of Basic Education that covers grades 1-8 students in 2011, and will cover up to grade 9 in 2012 . The school principal reported that his school enrolment in 2011 was 1213 students, 17 of whom had left school before the end of the year, and 127 were not promoted to the higher grades at the end of year exams.

As table 11 shows, there were 180 students in grade 1 . This number was further divided into three classrooms one of which is taught by a research participant who has been given a pseudonym Amina. The school principal reported that 22 of this number were retained in addition to seven who had left school before the exams. This figure (22 retained students) included four students from Amina's classroom.

All students can speak Tetun although most of them have a mother tongue other than Tetun as there are at least three local languages spoken in this town. Most parents are crop farmers and small business owners. The school is staffed with 40 teachers including three volunteers. 
Table 11: School B1 enrolment in 2011

\begin{tabular}{|l|l|l|l|l|l|l|l|l|l|}
\hline \multirow{2}{*}{ Grades } & \multicolumn{4}{l}{ All students } & \multicolumn{3}{l|}{ 'Dropped Out' } & \multicolumn{3}{l|}{ Failed Exam } \\
\cline { 2 - 11 } & M & F & total & M & F & total & M & F & total \\
\hline All grades, 1-8 & 602 & 611 & $\mathbf{1 2 1 3}$ & NR & NR & $\mathbf{1 7}$ & 63 & 64 & $\mathbf{1 2 7}$ \\
\hline All grade 1 (3 rooms) & 103 & 77 & $\mathbf{1 8 0}$ & 3 & 4 & 7 & 11 & 11 & $\mathbf{2 2}$ \\
Amina's room & 27 & 26 & $\mathbf{5 3}$ & 0 & 0 & $\mathbf{0}$ & NR & NR & $\mathbf{4}$ \\
\hline
\end{tabular}

Note: $N R=$ No Report .

\section{School B2}

School B2 is located in one sub-district town in which some parents are traditional crop farmers or are involved in fisheries and other small business. Most students speak Tetum as well as their own mother tongue. The school is staffed by 13 teachers including seven volunteers.

As the table 12 shows, the school covers grades 1-6 with 255 pupils in 2011. The school principal reported that 14 of the students had left school before the end of the year, and 61 pupils were retained at the end of year exams. Sixty six students were enrolled in grade 1, 18 of whom were not promoted to grade 2 in the end of year exams in addition to ten students who left the school earlier. More specifically, seven out of 35 grade 1 students from Ela (pseudonym)'s classroom were retained. 
Table 12: School B2 enrolments in 2011

\begin{tabular}{|c|c|c|c|c|c|c|c|c|c|}
\hline \multirow[t]{2}{*}{ Grades } & \multicolumn{3}{|c|}{ All students } & \multicolumn{3}{|c|}{ 'Dropped Out' } & \multicolumn{3}{|c|}{ Failed Exam } \\
\hline & $\mathbf{M}$ & $\mathbf{F}$ & total & $\mathbf{M}$ & $\mathbf{F}$ & total & $\mathbf{M}$ & $\mathbf{F}$ & total \\
\hline All grades, 1-6 & 122 & 133 & 255 & NR & NR & 14 & 19 & 42 & 61 \\
\hline All grade 1 ( 2 rooms) & 27 & 39 & 66 & 4 & 6 & 10 & NR & NR & 18 \\
\hline Ela's room & 22 & 13 & 35 & NR & NR & $N R$ & NR & NR & 7 \\
\hline
\end{tabular}

Note: $N R=$ No Report

\section{School B3}

School B3 is located in a rural village within the sub-district in which almost all parents are traditional crop farmers. All students speak Tetun beside their parent's mother tongue. The school covers grades 1-6 with 312 students in 2011. The school is staffed by nine teachers including four volunteers.

As table 13 shows, the school principal reported that 18 of the 312 students had left school before the end of the year; and 83 students were retained.

Grade 1 enrolment totalled 74 students in 2011, 16 of whom were reported to have left school before the end of the year and ten were retained at the end of year exams. Thus in total of grade 1,26 out of 74 students were not promoted to grade 2 .

Table 13: School B3 enrolments in 2011

\begin{tabular}{|l|l|l|l|l|l|l|l|l|l|}
\hline \multirow{2}{*}{ Grades } & \multicolumn{4}{l}{ All students } & \multicolumn{4}{l|}{ Drop Out } & \multicolumn{3}{l|}{ Failed Exam } \\
\cline { 2 - 12 } & $\mathbf{M}$ & $\mathbf{F}$ & total & $\mathbf{M}$ & $\mathbf{F}$ & total & $\mathbf{M}$ & $\mathbf{F}$ & total \\
\hline All grades, 1-6 & 158 & 154 & $\mathbf{3 1 2}$ & 8 & 10 & $\mathbf{1 8}$ & 49 & 34 & $\mathbf{8 3}$ \\
\hline Grade 1 & 37 & 37 & $\mathbf{7 4}$ & 8 & 8 & $\mathbf{1 6}$ & 4 & 6 & $\mathbf{1 0}$ \\
\hline
\end{tabular}


Context and school data summary

The three schools in district A are located on fertile land and are mainly surrounded by plantations which the population relies on for income. The land of schools in district B are mainly dry and the people rely on crops as their main income. While people in district A schools speak two mother tongues, people in district B school speak three mother tongues. The similarity amongst the two is that children in these schools can speak both Tetun and their own mother tongues.

As table 14 shows, schools were chosen from different locations in two districts. Two schools are from district towns, two from sub-district towns, and the other two schools are from two different villages

Table 14: Location of the case studies

\begin{tabular}{|l|c|l|}
\hline Case studies & Schools & Location \\
\hline \multirow{3}{*}{ Case study 1 (district A) } & A1 & District A town \\
\cline { 2 - 3 } & A2 & Sub-district A town \\
\cline { 2 - 3 } & A3 & Village A \\
\hline \multirow{2}{*}{ Case study 2 (district B) } & B1 & District B town \\
\cline { 2 - 3 } & B2 & Sub-district B town \\
\cline { 2 - 3 } & B3 & Village B \\
\hline
\end{tabular}


Furthermore, as table 15 shows, all schools were observed to have practiced grade retention over the grades including grade 1 students. Only one school appears to promote all grade 1 students in her class in 2011 with the exception of one who had left the school before the exams.

Table 15: School data in 2011

\begin{tabular}{|l|l|l|l|l|l|l|l|l|l|}
\hline \multirow{2}{*}{ Schools } & Grades & \multicolumn{3}{|c|}{ Students all grades } & \multicolumn{3}{c|}{ Students Grade 1 } & \multicolumn{2}{c|}{ Teacher status } \\
\cline { 3 - 11 } & & enrolment & $\begin{array}{l}\text { 'dropped } \\
\text { out' }\end{array}$ & failed & enrolment & $\begin{array}{l}\text { 'dropped } \\
\text { out' }\end{array}$ & failed & Permanent & volunteer \\
\hline A1 & $1-6$ & 1193 & 82 & 88 & 34 & 4 & 7 & 30 & 7 \\
\hline A2 & $1-6$ & 302 & NR & 31 & 47 & 1 & 0 & 10 & 5 \\
\hline A3 & $1-6$ & 346 & NR & 43 & 40 & 5 & 10 & 18 & 8 \\
\hline B1 & $1-8$ & 1213 & 17 & 127 & 53 & 0 & 4 & 37 & 3 \\
\hline B2 & $1-6$ & 255 & 14 & 61 & 66 & 10 & 18 & 6 & 7 \\
\hline B3 & $1-6$ & 312 & 18 & 83 & 74 & 16 & 10 & 5 & 4 \\
\hline Total & & 3621 & & 323 & 314 & 36 & 49 & 106 & 34 \\
\hline
\end{tabular}

Note: NR $=$ No Report

\section{Description of participants}

As table 16 shows, the participants' backgrounds are presented to provide key information about the participants' age, position, teaching experience, teaching qualification and the schools in which each of them worked. It indicates that most teachers had a teaching background. However, only the principal of school B2 met the new teacher qualification 
framework which requires a bachelor degree in education and training as the minimum qualification for a primary teacher.

Table 16: Backgrounds of the participants by case study

\begin{tabular}{|c|c|c|c|c|c|c|c|}
\hline $\begin{array}{l}\text { Case } \\
\text { study }\end{array}$ & School & Location & $\begin{array}{l}\text { Participants' } \\
\text { pseudonym }\end{array}$ & Age & Position & $\begin{array}{l}\text { Work } \\
\text { Experience }\end{array}$ & Qualifications \\
\hline \multirow{5}{*}{$\begin{array}{l}\text { Case } \\
\text { study } 1\end{array}$} & \multirow[b]{2}{*}{ A1 } & \multirow{2}{*}{$\begin{array}{l}\text { District } \\
\text { town }\end{array}$} & Celina & 54 & Teacher & 29 years & \multirow{5}{*}{$\begin{array}{l}\text { Secondary } \\
\text { certification } \\
\text { in teaching }\end{array}$} \\
\hline & & & Celestino & 42 & principal & 20 years & \\
\hline & A2 & $\begin{array}{l}\text { Sub- } \\
\text { district } \\
\text { town }\end{array}$ & Rita & 42 & $\begin{array}{l}\text { Teaching } \\
\text { principal }\end{array}$ & 17 years & \\
\hline & \multirow{2}{*}{ A3 } & \multirow{2}{*}{ Village } & Mariana & 57 & teacher & 24 years & \\
\hline & & & Januario & 44 & principal & 17 years & \\
\hline \multirow{5}{*}{$\begin{array}{l}\text { Case } \\
\text { study } 2\end{array}$} & \multirow{2}{*}{ B1 } & \multirow[t]{2}{*}{$\begin{array}{l}\text { District } \\
\text { town }\end{array}$} & Amina & 46 & teacher & 18 years & \multirow{2}{*}{$\begin{array}{l}\text { Secondary } \\
\text { certification } \\
\text { in teaching }\end{array}$} \\
\hline & & & Damião & 56 & principal & 31 years & \\
\hline & \multirow[b]{2}{*}{ B2 } & \multirow{2}{*}{$\begin{array}{l}\text { Sub- } \\
\text { district } \\
\text { town }\end{array}$} & Anito & 42 & principal & 18 years & $\begin{array}{l}\mathrm{BA} \text { in } \\
\text { teaching }\end{array}$ \\
\hline & & & Ela & 49 & teacher & 6 years & \multirow{2}{*}{ non teaching } \\
\hline & $\bar{B} 3$ & Village & Lukito & 59 & $\begin{array}{l}\text { teaching } \\
\text { principal }\end{array}$ & 6 years & \\
\hline
\end{tabular}

\section{Responses of the semi-structure interviews}

The participants' responses to the semi-structured interviews are presented under each question: 
Question 1: How do grade 1 teachers determine grade promotion or retention?

This question was asked of each teacher and responses varied across schools. A number of key ideas emerged and these have been grouped into the following themes.

\section{Examinations}

All schools from both case 1 and case 2 stated that they determine grade promotion-retention by conducting a written examination which takes place at the end of each school year. Exams were set by individual schools and therefore differ between schools.

\section{Examination subjects}

All subjects taught at grade 1 in schools of both case 1 and 2 were assessed in order to determine whether or not a student is promoted to grade 2 . The seven assessed subjects were Portuguese, Tetun, Maths, Environmental Education, Art and Culture, Physical Education and Hygiene, and Religion.

\section{Scores}

All teachers from case 1 and 2 stated that the minimum score for a student to be promoted was 42 out of a possible 70 for all seven subjects. However, the teachers' answers differed when they were asked for the minimum score for Portuguese and Maths. Two participants from case 1 and three $(\mathrm{N}=3)$ from case 2 stated that in order to be promoted, a student needed 
to gain a score of 6 in Portuguese, while one teacher from case 1 stated 5.8 or 5.7 was required.

Two teachers from case 1 and two from case 2 stated that they gave 6 as the minimum score for Maths for a student to be promoted. One teacher from case 2 stated 5 and another teacher from case 1 stated 5.8 or 5.7 .

\section{Key skills}

All six teachers from both case 1 and 2 required students to be able to read and write and count in Portuguese in order to be promoted from grade 1 to grade 2:

"My criteria is 'know' [how to] read, to write, and to count" (Celina, case 1)

\section{Portuguese skill}

Two teachers from case 1 and one from case 2 required students to be able to read words, two from case 2 and one from case 1 required only reading and writing syllables in order to be promoted to grade 2 . In addition to reading and writing skills two teachers from case 1 and one from case 2 insisted students know some Portuguese words:

"[Students] should know [how to] read and write a word. And if they know some Portuguese word they can be promoted"(Celina, case 1).

"Children [should] know writing and reading words by spelling, also know some Tetun and Portuguese" (Rita, case 1).

"I scored 6 if students know some words by mentioning words following images".

(Amina, case 2). 


\section{Maths skills}

All six teachers from both case 1 and 2 required students to be able to count numbers in Portuguese, but differed in their required skill levels. Three teachers (Amina, Ela and Lukito both from case 2) required numbers 1 up to 20, while teachers from case 1 required different numbers: Celina required 1 up to 50, Mariana required 1 up to 100 while Rita didn't state the limit.

All of the teachers required a simple calculation of addition and subtraction. One teacher from case 2, however, also required students to have some skills in multiplication and division as well as addition and subtraction.

"They know addition, subtraction, multiplication and division they can be promoted". (Ela, case 2).

\section{Attitude}

In addition to the scores and skills, some teachers required students to meet attendance criteria. Again, this varied between schools with five teachers mentioning retaining students if their attendance is low. Three of these teachers ( 2 from case 1 and one from case 2 ) did not mention how low. In case 2, one teacher stated that he retains a student if s/he missed up to 30 days a year; and another teacher required absences not to total more than twice a week. Yet another teacher had no attendance requirements. 
Furthermore, one principal (case 1) stated that he would retain a student in his school if the student exhibited a bad attitude or insulted his or her teachers.

\section{Document analysis}

As previously described, documents pertaining to grade promotion and retention were requested from each school.

\section{Policy document}

All schools reported they had policies relating to grade retention. However, no school provided a written copy of these documents. Further questioning revealed these were not written policies but verbal understandings between the school principal and his or her teachers. Principals reported their belief that this policy originated with the MoE. Verbal requests to the MoE for this information were made, however, no documents were produced. It appears that none have been issued relating to grade retention practices for grade 1 . Further searches revealed a manual that contains a guide for Grade 9 and 12 only. This manual was issued to regulate the national examinations for grade 9 and 12, the last year of Basic Education and for grade 9 and 12. At these levels, Grade 9 students were required to achieve a minimum mark of 20 out of 50 for five subjects: Portuguese, English, Maths, Science and Social Science (MoE, 2011). Other documents included examination papers relating to those exams; tests used to retain or promote students, and exam reports. 


\section{Examination papers}

Analysis of examination papers revealed that schools exams for grade 1 promotion-retention were written in Portuguese with the exception of the Tetun subject exam that was written in Tetun. Five schools presented the researcher with their written question instructions. The exam questions required students to not only read syllables and words but to show an understanding of the meaning of a simple text. An example is shown in Appendix I. Students were asked to fill the gap in sentences by choosing words in a three sentence text.

\section{Students' exams report}

The researcher was able to retrieve some of the students' exam reports from four schools. In two of these schools, he found the students' failing exams gained under 42 marks; but as previously mentioned, Celina (case 1) also failed a student who received 43 marks (Appendix J).

Another teacher (Rita, case 1) claimed that she had no students score below 42, therefore no grade 1 students were retained at the end of 2011.

\section{Examination scripts}

The researcher analysed exam scripts from those schools that were able to provide these data $(\mathrm{n}=5)$. He found some concerns on the exam scripts, as presented below: 


\section{Unclear instructions}

In school B1 (case 2) a Portuguese language exam (Appendix K) contained ten boxes that were located under words: Bata \& Pau, Dedo \& Flor, Piao \& Bola, Camija \& Roda, and Asa \& Mão. Students were asked to fill the boxes that were located under letter A, B, C \& D with an $\mathrm{X}$.

\section{Wrong marks on students' work}

In school A3 (Appendix L) a score of 6 out of 10 was given to a student for his/her unclear Tetun work, and a wrongly answered maths equation $(1-2+1=2)$ was judged as correct (Appendix M)

\section{The context of exam content}

In school B3 (case 2) students were asked to show the underlined letter Z of Zebra (Appendix $\mathrm{N})$. Students of this school were mostly village students who may not know what Zebra is but would know what horse is.

Question 2: What role does formative assessment have in students' learning prior to grade retention?

The researcher split this question into two sub-questions in order to guide the teachers' responses as: "how do teachers define the extent to which students have learnt during a lesson?", and "how do they use the assessment results?" 


\section{How do teachers define the extent to which students have learnt during a lesson?}

When asked to describe how teachers know that students had learned what was being taught, the teachers $(\mathrm{N}=6)$ gave different responses and these are grouped in themes as shown below:

\section{Observations}

Two teachers from different cases, Mariana (case 1) and Ela (case 2) provided answers that are themed as observation of students' engagement in the class activities. Below are their comments:

"Look at his/her [the student]'s activity, his/her ability, his/her study. Look at like when I teach him/her at home"(Mariana, case 1).

"I look at their [students] daily attendance, their interest in learning...”(Ela, case 2)

\section{Tests}

Two other teachers, Celina from case 1, gave an example of a test she would use to assess a student's learning, whereas Lukito from case 2 mentioned 'test' at the end of a lesson. They commented:

"Sometimes in a book, I picked up a 'lafaek' magazine I asked if s/he knows"

(Celina, case 1).

"When we have finished teaching a lesson we conduct a test to measure whether or not children have understood the lesson" (Lukito, case 2). 


\section{Students' different ability}

When asked to describe how teachers know that students had learned what was being taught, Rita (case 1) and Amina (case 2) gave responses that are more related to students who are disabled from birth. Below are their responses:

"I think we should learn psychology, sometimes children with their own born character, some can learn fast, but some would take time"(Rita, case 1).

"In my class one of those who did not pass had special behaviour, he didn't follow the lessons, not even holding pencils"(Amina, case 2).

Given most responses of the teachers were not satisfactory, the researcher then asked whether or not the teachers conduct assessment to define the extent to which students have learned during a lesson? All participants responded yes, to say that they conduct tests. Based on this understanding, the researcher then asked the following question:

\section{How did teachers use the assessment results?}

Responses of this sub-question are grouped into themes under the following: report, revision of lessons, and prize giving.

\section{Report}

Three participants from case 1 and one from case 2 reported that their students' assessment results were kept in their report books for their information and later reporting to the parents:

"I put the test results in a Report [book] to show the parents as well as to the students" (Mariana, case 1). 
"I always used [them] for my reports, to see those who had good scores and those who received low scores" (Celina, case 1).

“The test results, we put on [students]' report to compare students who received good scores and those who received low scores" (Rita, case 1).

"We should put them on a book like formative test for us to know" (Lukito, case 2).

\section{Revision of lessons}

Three out of six teachers $(n=3)$, two from case 1 and one from case 2 replied that the assessment results were used as the basis for a revision of lessons for the students, mainly for those with low scores:

"I give attention [specifically] to those who received low scores, [and] approaching and provide motivation to them.. and call attention of their parents"'(Amina, case 2).

“...to see their notes and continue to provide them revisions"(Ela, case 2).

"...teaching them again...grouped those who received low scores together away from those who received good to give them more attention" (Mariana, case 1).

\section{Prize giving}

Rita (case 1), reported that the assessment results were used not only to report to parents, but also were used as a basis for prize giving:

"The results of the tests were the students' [scores] we give those who [received] good scores [a] simple gift to motivate them to attain better learning" (Rita, case 1). 
Responding to the follow up question of what Rita did for those who received low marks, she replied that she also offered small gifts like pencils and sweets to the weaker students, including those who had low marks:

"Those who received low marks we gave them small gifts, e.g. pencils or sweets".

(Rita, case 1)

Question 3: What, if any, strategies do teachers use to improve students' learning in order to prevent them from being retained in grade 1?

Six participants $(\mathrm{N}=6)$ gave different answers to the above question, and these responses are grouped into the following themes:

\section{'Train students' to write words}

One teacher explained that following poor test results she paid more attention to the weak students by training them: holding the students' hands to train them to write, asking them to write on the blackboards, and expecting them to learn better and pass exams. The teacher commented:

"I gave [specific] attention to the weak students. Holding their hands to write. Asked them write on the blackboard as well" (Celina, case 1).

However, in 2011 she did not promote seven students out of the 34 remaining students with 24 out of 58 having left for a new Portuguese school. The teacher commented: 
"This year seven students who come every day [but] were only sitting, didn't want to write, because of that they failed" (Celina, case 1).

Similarly, Amina (case 2) explained that recently she asked her weaker students to write words. However, four of Amina's 53 students were not able to write letters nor read nor even recognise the vowels until the end of the school year, therefore they were not promoted to grade 2 .

\section{Pay more attention to the weaker students}

Mariana (case 1) explained that to prevent students from grade retention she paid more attention to the students who had learning problem by grouping them together in the class to give them priority in the class activities. In other words, "priority" was described as giving these students greater access to the teacher.

\section{Homework}

Differing from other teachers Ela (case 2) stated that her intervention she used to prevent students from being retained was to provide continuous assessment and homework. Ela commented: "I continue assess them, finding means...give homework to them".

Ela was disapointed that her efforts were not enough to have all students get promotion to grade 2. She commented: "My efforts may not enough to have all students get promotion" 


\section{Revision of the lessons}

Another teacher, Lukito from case 2 stated that to prevent students from being retained he revised the lessons they had not understood. Lukito reported that after attending the lesson revisions some students' learning outcomes were better but some remained the same.

\section{Replace the teacher}

In a different conversation, Rita, a teaching principal from case 1 explained that last year she found that grade 1 teachers had not produced a good learning outcome for students, she transferred the teacher to another grade and placed herself as a teacher for grade 1 . The result was that all her students were promoted with the exception of four underage students who left earlier for a pre-school, and another one left the school without notifying the school.

Question 4: In relation to grade retention what factors do grade 1 teachers believe inhibit students' achievement of learning outcomes?

This question was asked of each of the ten teachers and principal participants. The factors that they believe inhibited students' learning outcomes were varied among schools and even differed among the participants. A number of key ideas emerged and these have been grouped into themes, as presented below: 


\section{Overcrowded classes}

Five participants $(\mathrm{n}=5)$ from different cases; two from case 1 (Celestino and Celina) and three from case 2 (Damião, Amina and Ela), stated overcrowded classrooms in their schools were the most problematic factor inhibiting their students' learning. Celina, who had 58 students in her classroom in 2011, lamented:

"Too many students, we don't know [how to teach] children individually"

(Celina, case 1)

Amina who had 53 students observed:

"Many students, many children did not pay attention to the teacher" (Amina, case 2).

Another teacher, who had 35 students, stated she couldn't effectively teach such a high number of students. She further stated it was difficult to manage 35 six or seven year old students.

When the researcher asked what would be the ideal number of students for a classroom, the teachers provided different responses. Celina suggested 30, Amina 35 and Ela suggested 25 students.

\section{Insufficient number of chairs and tables}

In Timor-Leste schools, a chair and table are joined, and designed so two students can sit at the same table. Participants stated that in addition to overcrowded classes, insufficient chairtables for students was another factor inhibiting teaching-learning activities. Chair-tables 
were not available for every student in the class. This situation required an adjustment by placing three students on a chair-table set that was designed for only two students. Participants reported that even with the adjustment of three students on a chair-table, the seating spaces were still inadequate for every student. Some students had to sit on the ground while they were being taught:

"Many students [with] insufficient chair-tables [therefore] some students sit on the ground" (Celina, case 1).

The principal of the school confirmed what had been stated by Celina:

"Each teacher has [about] 57 students, [they] sit in three's and [even] some should sit on the ground" (Celestino, case 1).

Ela, a teacher from school 2, district B, complained that:

"The biggest challenge is chairs. Insufficient chairs, three students sit on one set of chair-table” (Ela, case 2).

\section{Lack of appropriate learning materials}

Four participants, three of whom were principals (Celestino, Damião, and Anito) and one teacher (Amina) raised the concern of books and supporting learning materials for their schools. Celestino, the principal of school A1, raised her concern of inadequate books for each grade level:

"There are no specific books for each grade level. One book is used for many grades".

(Celestino, case 1). 
The principal suggested that they would like books for every grade as had been the practice during the Indonesian occupation:

"Lack of books for students as well as for the teachers. Sometimes teachers use whatever book they have [to teach] in the classes. Then [a lack of] teaching materials for the students in the classes [is also an issue]" (Damião, case 1).

"Another problem is Portuguese. It is too difficult for me particularly as there no books for self study" (Amina, case 2).

"[There are] insufficient books such for subjects such as arts and culture, and physical education" (Anito, case 2).

\section{Low teacher qualifications}

Three out of ten participants are principals from district B. They each raised concerns about teachers' qualifications, claiming these as a factor that inhibited students' learning outcomes:

"Training for the teachers [is needed]" (Damião, case 2).

"The contract or volunteer teachers are all young, have no courses about teaching and children's development" (Anito, case 2).

"Generally, the teaching methods of teachers that might not correct" (Lukito, case 2).

\section{Lack of parent support}

Three other teachers (Celina, Ela and Lukito) raised their concern about parents' cooperation. They claimed that the lack of parents' support for their students' learning is another factor that inhibited students' learning outcomes: 
"The principal never invites parents [to school]...last year I invited them but only some came" (Celina, case 1).

"The greatest challenge is the parents who have no interest in helping their children to learn"(Ela, case 2).

"One problem is children do not study at home" (Lukito, case 2).

\section{Low student attendance}

This problem was especially reported by school A3. The principal of this school reported that student attendance in his school is low due to two main reasons. One reason is that students are often absent from schools on Tuesdays, Thursdays and Fridays due to the open markets that occur on those days in different villages around the school. Secondly, students are absent because they attend traditional ceremonies that take place in the community that often last for weeks and even up to a month.

“There are open markets three times on Tuesdays [in village A], Thursdays [in village B] and on Fridays [in village C]. Many children with economic reasons, especially in the season like this, there are mangoes, jackfruit, cassava, vegetable, [their] parents force them to go to sell these things on the three markets. So in a week they come three days to the school and go to the markets three days, that's why these children do not get enough benefits from the school"(Januario, case 1).

“Traditional or cultural parties such as 'Koremetan' and 'Umalisan' last long. It takes two to three weeks and even up to a month. Children also joined their parents in taking part in these ceremonies with the reasons that the parties were about their grandparents, 
and the traditional holy house belong to the children too. Children should be there in the ceremonies in order to receive holy things" (Januario, case 1).

Question 5: What beliefs do grade 1 teachers hold about grade retention practices?

This question was asked of all teachers and principal participants in four sub-questions. Responses varied with a number of key ideas emerging. Again these have been grouped into themes.

\section{Low learning outcomes}

All participants $(\mathrm{N}=10)$ believed that the reason for grade retention was because grade one students had gained a score of below 42 out of 70 in the end of year examination. Their comments attributed these low scores to a range of possible reasons:

"Because their scores did not reach the standard" (Lukito, case 2).

"Because their parent did not pay enough attention to them...because they did not actuallylearn [how to] write and read...stuff that teachers taught” (Ela, case 2).

"Because too many students in [a] class, because they can't properly learn, some [of them] also are often absent [from school] therefore they did not pass" (Damião, case 2).

"They failed [exam] because they did not know. [However] when they repeat...I will give them motivation to learn properly"(Amina, case 2).

"We look at score, children's knowledge from trimesters 1-3.. we also look at children's class participation, as well as their attitudes as a student" (Januario, case 1). 
Additionally, two teachers and two principals perceived that low scores linked to either students' lack of interest in school or their age:

"Some children don't have interest in their own schooling. They think they don't have [a] future in schooling. They are pushed by their parents and their teachers to go to school" (Rita, case 1).

"Because of their daily habits that they did not want to learn" (Celina case 1).

"Underage students and those who did not know [how to] read, write and count".

(Celestino, case 1).

"Many grade 1 students are five years old, [while] grade 2 lessons are a bit harder. Therefore we did not let them pass for them to learn again at Grade 1" (Anito, case 2).

\section{A second chance for better learning}

Teachers were asked to describe the objective of grade retention. Five participants stated their belief that grade retention led to better learning:

"The aim is to ensure they well understand grade 1 lessons before pass" (Anito, case 2).

"To be able to continue [their] studies in the future. For them to [have] a better learning"(Damião, case 2).

"If student do not know...the best [decision] is to fail for him to study again next year" (Celestino, case 1).

"I [should] find means to ensure you really know" (Celina, case 1).

"Making an effort for them [the failing students] to get promotion" (Mariana, case 1). 
"I hope the failing students do come back for repeating [the grade], I [would] give them awareness about the reasons of their failure [in order to get them improve their learning]" Amina (case 2).

A further three participants stated that grade retention provided a chance to motivate students in order to change their attitude and motivate them towards learning:

"When they came back to the grade, teachers and myself should give them motivation to improve their attitudes for learning to pass at the end of the school year".

(Januario, case 1).

"[However] when they repeat...I will give them motivation to learn properly".

(Amina, case 2)

\section{Better learning outcomes}

Most teachers and principals declared that after retention their students achieved better learning outcomes. Only one of them (Celina, case 1) lamented that in spite of her efforts, students' learning outcomes after retention still depended upon whether or not their parents helped them:

"I look for ways for the students to really understand, but, [this is also] depended to the parents. If they helped their children their children can be promoted"(Celina, case 1).

\section{Stance for grade retention}

When considering whether or not grade retention is a good practice, all participants from both case 1 and 2 said they agreed with grade retention practices However, their responses differed when they were asked what their stance would be if a policy was introduced to abolish grade 
retention. Seven participants responded negatively, including one who labelled his weaker students as stupid:

"I would not agree to such law because it means all students including the stupid ones should be promoted while we want a quality of education" (Lukito, case 2).

"If such a law takes place...Too many students, an average of 45 in each class. Many of these children would just be promoted with knowing nothing" (Damião, case 2)

Two participants from different cases Rita (case 1) and Anito (case 2) suggested preconditions to implementing a policy to abolish grade retention. Rita proposed compulsory pre-school experiences for all children preparatory to enrolling in grade 1:

"If the policy comes true accompanied with a compulsory law for preschool, this can help students to be promoted with quality" (Rita, case 1).

Interestingly, in one school, participants suggested the removal of grade retention would motivate staff to work harder.

Anito, case 2 commented that if there was no grade retention he would like to increase - and would advise his teachers to increase - the effort put into teaching. He also proposed an upgrading of teaching qualifications for under-qualified teachers and, additionally suggested subsidies for teachers to run extra lessons in order to ensure students' promotion on a merit base:

"If the law takes place then I should make efforts as well as my teachers should make efforts for the students to be promoted with quality. [However], this law should come with preparation, teacher training about how to teach, and also subsidy to motivate teacher to do extra service" (Anito, case 2). 
A teacher in the same school shared these sentiments, stating that abolishing the practice of grade retention would increase her efforts to ensure her students pass. She suggested that not having grade retention would mean she would feel compelled to work harder to ensure all students were promoted:

"I would agree if the law exists. As teacher, I should make efforts in order to get all my students promoted" (Ela, case 2).

\section{Document analysis}

\section{Students' exam reports}

Two schools from case 2 and one from case 1 provided the researcher with reports for those students who failed exams in 2011. Reports from two of these schools related to students who had been retained at the end of grade 1 . Their examination results showed they had both gained less than 42 out of a possible 70 marks, the perceived minimum standard required by the Ministry of Education in order for a student to be promoted.

In one school (case 1) the scores of those students who were retained in grade 1 showed that one student who was retained had a score of 43 .

Both the principal and the teacher in this school had stated that the required score for promotion was 42 . This score of 43 appeared as an anomaly amongst grades for other retained students who had consistently scored 41 or below. 
As discussed in the section describing participant interviews, most participants claimed that those students who repeated grade 1 at the end of the year had better learning outcomes in the following year. However, when the researcher requested documents that were evidence of this claim most school were not able to provide one. They suggested that these documents had been distributed to the parents. Only one school (case 1) was able to obtain a student's report and this was gained through a request the school made to the child's parents. Perusal of this report showed that the student failed to get promotion in the previous year with a score of 41 for the seven subjects taught at grade 1 . The report also showed that the student's score after retention was 50 and this was the highest mark given to his year group.

\section{List of students' Portuguese \& Maths national test}

Another school (case 1) reported that three students who had repeated grade 6 gained the highest marks in a national examination for Portuguese and Maths.

\section{Analysis of school data}

Analysis of 2011 school data (Table 15) revealed that five out the six teacher participants retained 49 out of 314 grade 1 students in addition to 36 who left schools before the end of year exams. Those who left school before the exam and those who were failed at the exams comprise the number of failing students. Overall, almost three out of ten students failed in their schooling in 2011. This figure is rather small compared to some individual schools. For example school B2 in district B (case 2), the number of failing grade 1 students reached four 
out of ten students, following by school A3 in district A (case 1) with 37 percent, and school B3, district B (case 2) with 35 percent.

\section{Grade promotion-retention criteria}

In this study, it is evident that across all cases there is inconsistency in how teachers determine whether or not to promote or retain students.

Table 17 shows, the range of criteria used in promoting or retaining students. There is no prescribed policy that regulates grade promotion-retention at grade 1. However, all schools from both cases practised grade retention, and these practices were based only on verbal communication among the teachers, school principals and school inspectors.

Table 17 also shows the inconsistency in teachers' expectation relating to the following points:

- More teachers in case 2 than case 1 would fail students who receive less than six band score in Portuguese. They expected at least six points.

- Most teachers in both cases would fail students who receive less than six band score in maths. Teachers from the same case have different expectations.

- More teachers in case 1 have higher expectation in reading than those from case 2. Teachers in case 1 also have higher expectation in counting than teachers in case 2.

- More teachers in case 1 than case 2 required attendance criteria. 
- There was a teacher in case 1 but none in case 2 who considered student attitude.

Table 17: Tools and mechanism of grade promotion

\begin{tabular}{|c|c|}
\hline Findings & Respondents \\
\hline No written policy about grade retention for grade 1 & Both cases 1 and 2 \\
\hline Grade promotion is determined through examinations & Both cases 1 and 2 \\
\hline Examinations are conducted across seven subjects & Both cases 1 and 2 \\
\hline Examinations are conducted in Portuguese & Both cases 1 and 2 \\
\hline The perceived standard for promotion: 42 points & Both cases 1 and 2 \\
\hline 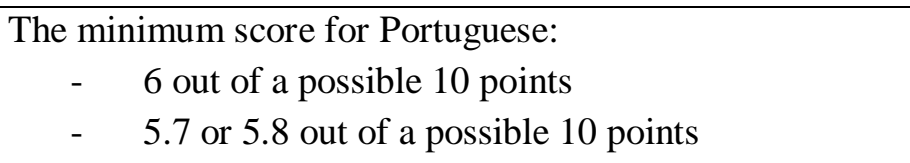 & $\begin{array}{l}2 \text { from case } 1 ; 3 \text { from case } 2 ; \\
1 \text { from case } 1\end{array}$ \\
\hline 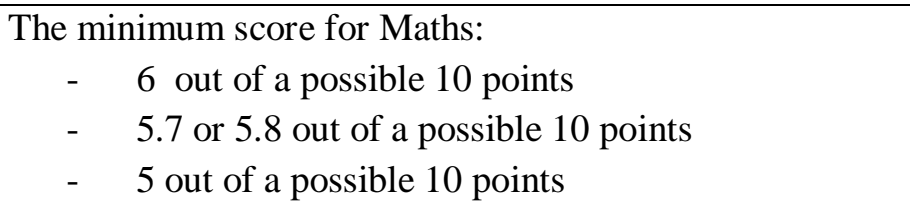 & $\begin{array}{l}2 \text { from case } 1 ; 2 \text { from case } 2 \\
1 \text { from case } 1 \\
1 \text { from case } 2\end{array}$ \\
\hline $\begin{array}{l}\text { The minimum Portuguese skills: } \\
\text { - Reading and writing words } \\
\text { - Reading and writing syllables }\end{array}$ & $\begin{array}{l}2 \text { from case } 1 ; 1 \text { from case } 2 \\
1 \text { from case } 1 ; 2 \text { from case } 2\end{array}$ \\
\hline $\begin{array}{l}\text { The minimum skills for maths: } \\
\text { - Counting and writing up to } 20 \text { numbers } \\
\text { - Counting and writing up to } 50 \text { numbers } \\
\text { - Counting and writing up to } 100 \text { numbers }\end{array}$ & $\begin{array}{l}3 \text { from case } 2 \\
1 \text { from case } 1 \\
1 \text { from case } 1\end{array}$ \\
\hline Student's attendance is a requirement for grade promotion & 3 from case $1 ; 2$ from case 2 \\
\hline Student's attitude is a requirement for grade promotion & 1 from case 1 \\
\hline
\end{tabular}




\section{The role of formative assessments in students' learning}

As table 18 shows, participants even from the same case gave different responses to the question of how they determine the extent to which students have learned during a lesson. Similar characteristics occurred in responses to the question about how the teachers used the assessment results. More teachers in case 1 than in case 2 appeared to use assessment results for reporting to parents. Whereas more teachers in case 2 than in case 1 would use the assessment result for revising lessons.

Table 18: Responses regarding formative assessments

\begin{tabular}{|l|l|}
\hline Findings & Respondents \\
\hline $\begin{array}{l}\text { How the teacher determines the extent to which } \\
\text { students have learned during a lesson: }\end{array}$ & \\
- Observations & 2 teachers (both cases $1 \& 2)$ \\
- Tests & 2 teachers (both cases $1 \& 2)$ \\
- Given disability & 2 teachers (both cases $1 \& 2)$ \\
\hline How the teachers use the assessment results: & \\
- Report & 4 teachers (3 case $1 ; 1$ case 2) \\
- Revising lessons & 3 teachers (1 case $1 ; 2$ case 2$)$ \\
- Prize giving & 1 teacher (case 1$)$ \\
\hline
\end{tabular}

\section{Intervention tools teachers used to improve low achieving students}

As table 19 shows, teachers from both cases 1 and 2 and within each case have different teaching intervention techniques. They do not have anything in common. 
Table 19: Responses regarding teachers' interventions

\begin{tabular}{|l|l|}
\hline Findings & Respondents \\
\hline 'Train students' to draw letters & 2 each from both cases \\
\hline Grouping low achieving students all-together & 1 from case 1 \\
\hline Give students homework & 1 from case 2 \\
\hline Revision of lessons & 1 from case 2 \\
\hline Replace the teacher & 1 from case 1 \\
\hline
\end{tabular}

\section{Factors teachers believe inhibit students' learning}

This question was asked of each of the ten teachers and principal participants. The factors that they believe inhibited students' learning outcomes are varied among schools and even differ amongst the participants. As table 20 shows, all participating schools in both cases are found to have large class sizes. Insufficient chair-tables are more evident in case 1 than case 2 . Lack of appropriate learning material was reported in more schools in case 2 than case 1. Low teacher qualifications were reported by schools in case 2, and evidenced in the form of document analysis across all schools. Only one principal from case 2 met the teaching qualification framework. A lack of parental support was reported mostly from schools in case 2, and student absenteeism was reported in case 1. 
Table 20: Factor inhibiting students' learning

\begin{tabular}{|l|l|}
\hline Findings & Respondents \\
\hline $\begin{array}{l}\text { Overcrowded classes: } \\
\text { The class sizes ranged from } 35 \text { to } 58 \text { students }\end{array}$ & 2 from case 1; 3 from case 2 \\
\hline $\begin{array}{l}\text { Insufficient chair-tables: } \\
\text { Three students sit on chair-tables, some sit on the ground }\end{array}$ & 2 from case $1 ; 1$ from case 2 \\
\hline $\begin{array}{l}\text { Lack of appropriate learning materials: } \\
\text { No books for every subject nor other learning materials }\end{array}$ & 1 from case 1; 3 from case 2 \\
\hline $\begin{array}{l}\text { Low teaching qualification: } \\
\text { Most teachers are under the required qualification level }\end{array}$ & 3 from case 2 \\
\hline Lack of parental support & 1 from case $1 ; 2$ from case 2 \\
\hline $\begin{array}{l}\text { Low students attendance: } \\
\text { In school A3 students attendance is low during seasonal harvest }\end{array}$ & 1 from case 1 \\
\hline
\end{tabular}

\section{Beliefs grade 1 teachers hold about grade retention practices}

This question was asked of all teachers and principal participants in four sub-questions. Responses varied with a number of key ideas emerging. These have been grouped into themes.

\section{Academic performance}

Participants from both cases 1 and 2 stated that the main reason for grade 1 retention was that student academic performance fell under the national standard. However, one participant from case 1 included students' participation in the class as well as their attitude towards the teaching staff as part of the criteria for grade retention. 


\section{Grade retention leads to better learning}

All participants from both cases 1 and 2 believe grade retention leads to better learning outcomes and argued that grade retention is a chance for the teacher to make an effort and motivate students to learn.

\section{Grade retention versus social promotion}

More participants in case 1 than those in case 2 disagreed that grade retention should be abolished. Conversely, more participants in case 2 than those in case 1 said they would agree if grade retention were abolished with pre-conditions, i.e a compulsory pre-school education for all children before their enrolment at grade 1; an upgrade of teachers' qualifications; a reduced teacher pupil ratio; and the provision of a subsidy for teachers as a reward for their extra efforts.

In the following chapter the findings of this study are discussed before consideration of the implications of this study for policy makers in Timor-Leste. 


\section{Chapter 5: Discussion of findings}

This chapter will critically discuss findings of the semi-structured interviews that were conducted with ten participants including four teachers, two teaching principals and four principals. The participants were from two districts of Timor-Leste. Discussions are presented in five sections, each of which represents the five research questions of this study.

Section 1 involves discussions about mechanisms that teachers used to promote or retain grade 1 students. Findings showed that grade retention is mainly determined by students' academic achievement through the end of year exam. However, in some schools nonacademic performance such as attendance and attitude also counted towards grade promotion. Importantly there is a lack of consistency amongst schools regarding promotion and retention criteria.

Section 2 discusses assessment practices that teachers use to inform students' learning progress and the teacher's teaching in order to improve the students' achievement of learning outcomes. Thus the discussion focuses on how teachers conduct the assessment for learning.

Section 3 is about interventions that teachers use to prevent students from grade retention. Importantly, teachers, at a certain amount of efforts try to improve students' learning. However, due to classroom limitations and lack of knowledge, teachers continue to retain students. 
Section 4 discusses factors that teachers and principals believe inhibited students' achievement of learning outcomes. Classroom condition, teacher qualification, and students' attendance are key discussion points. The fifth section is about the teacher and principal participants' beliefs about grade retention. The participants' beliefs are strongly linked to their decisions about grade retention.

Key themes that are discussed in this section include the following:

- Grade promotion or retention practices

- The role of formative assessment

- Teachers' interventions

- Factors teachers and principals believe inhibit student achievement

- Teachers and principals' beliefs about grade retention

Section 1: Grade promotion or retention practices

This section focuses on discussion relating to the criteria and mechanisms teachers use to promote or hold back students at grade 1. Both academic and non-academic performance was considered.

\section{Promotion and retention criteria}

Promotion and retention decisions related to both academic and non-academic criteria. 


\section{Academic criteria}

As mentioned in the chapter four, the teachers' reports and exam scripts show that all participating schools conduct end of year exams to measure academic achievement of the students. From the results of these exams, teachers determine grade promotion or retention. Pass/fail and promotion/retention criteria varied between and across schools, and did not necessarily align with Ministry guidelines that students in grade 1 count in Portuguese up to 100 (MoE, 2005b). Other examples highlighted discrepancies across schools in relation to teacher requirements of students in literacy with some schools expecting students to be able to spell and read syllables as the basic measure and others expecting them to read words (MoE, 2005a).

Interestingly, there is no written law or any guidelines that regulate grade retention. In some case studies' teacher judgement relating to retaining or promoting a student was subjective. This aligns with social constructivism (Denscombe, 2010) where social reality has subjective meaning and people can decide and do what they like. Subjective decisions are made without reference to objectivity and in the case of these schools in Timor-Leste subjective decisions are made relating to examination content, pass levels and student attendance and attitude.

\section{Teacher errors}

Students may have been given no marks for their exams as a consequence of teacher error. For example, one Portuguese exam (A1, case 2) provided exam instructions so complicated, 
that even the researcher had difficulty understanding what was required. It would seem that most six year old students would be marked wrong on this answer, and would not gain a mark for that question. In terms of grade promotion - this poorly worded exam instruction would send a message that the student is not doing well as they had this section marked incorrectly where in reality, it was the way the question was worded that provided the difficulty. If enough questions are poorly worded, it is possible that students could fail the exam. In that case, the student's failure to get promotion would not be evidence of his or her own learning but it was because their teachers or examiner had failed to provide clear instructions.

Further evidence of teacher error that provided misleading feedback was found on perusal of exam scripts in school A3, case 1. One student gained a promotion score of six out of ten for his unclear answers, and another student gained a score point for the following maths equation that he answered incorrectly but the teacher marked as correct: $1-2+1=2$. Both students would consequently benefit from these scores and may lead them to be promoted to grade 2. However, the students would not learn or correct their mistakes because they thought their answers are correct. Thus the mistakes may remain a mistake in the students' minds, whereas the assessment results that can be useful to learning are impossible. In fact a summative assessment result can also be used for learning (Harlen, 2005).

Unlike the case in school A1, case 2 in which the students were negatively affected by unclear instruction, students in school A3, case 1 benefit from the mistakes of their teachers 
in terms of grade retention practice. These students were potentially able to be promoted to grade 2 as their scores increased by wrong and unclear answers that are given a correct mark. The teacher assessment action occurred due to the assessment practices that relied heavily on teacher judgement.

\section{Possible solutions}

Given the negative impact grade retention may have on the life of young children (Jimerson, Anderson, \& Whipple, 2002) it is important that grade 1 teachers have the minimum teaching qualification for primary education, and clear guidelines are established stating the condition under which a student may be retained or promoted.

Another possible response to the variation in exam expectations could be the introduction of across school moderation practices. Moderation is a form of quality control through which assessment procedures and outcomes are checked, i.e. by other teachers to ensure that there is consistency in the resulting outcomes before the final mark is given (Maxwell, 2007). In other words, moderation is a series of procedures undertaken by more than one teacher in order to make sure that a grade mark given for a student's work is consistent with the quality of the work (Wyatt-Smith et al., 2010). In a very simple form of moderation, a student's work is judged separately by two teachers, and then they meet to discuss and reach a consensus for a final grade mark if their individual grade marks differ. A moderation process for grade 1 assessment may be seen as an unnecessary intervention because most teachers perceive, grade 1 lessons are very easy with the content required at that level not considered difficult. 
However, given that teachers may make mistakes in their judgements for whatever reason as evidenced by the teacher who retained a student with a score of 43 - introducing moderation may be relevant, especially in the large class sizes such as those in the participating schools of this study where numbers ranged from 35 to 58 students.

\section{Non-academic criteria}

Participants also stated that students who fail to attend the exams are not likely to be promoted, with attendance minimum requirements varying between schools. Attendance in schools in Timor Leste is linked to cultural practices. Many students in school A3, case 1 are absent from school up to three days in a week because they are required to help their parents sell seasonal fruit and vegetables at the market. The parents appear to face a dilemma: whether to let their children go to school or, to ask them to go to the market. The dilemma that the parents face is due to their understanding of the benefit of both schooling and the market. While schooling is the right of children to learn the prescribed curriculum, the market economically and immediately benefits the family. While schooling lasts the whole year, seasonal harvest fruits and vegetables may last only a few weeks. School children cannot do two different things at the same time but they must do one first before the other. It would appear that the parents finally opt for the children to take the fruit and vegetables to the market otherwise these seasonal foods would become spoiled. After the market, parents are likely to let their children go back to school.

It would stand to reason, that if the parents are conflicted about whether or not to send their children to school or to market, the children could also feel this conflict: whether or not to 
obey their parents' demand to go to the market, or going to school to study. If they obey their parents, this means they please their parents but they neglect their teachers. Conversely, if they ignore their parents, they can be punished. While at home children face parents, at school they face teachers. A further study is needed to identify how this situation might affect students and whether or not it impacts on their inclination to remain at school.

Ministry expectations (MoE, 2009) are that students attend school from Monday to Saturday with the exception of public holidays. Clearly, this is not the case for a number of students. One possible solution to the problem of absenteeism where it is due to cultural practices could be to involve parents, teachers and the wider school community in identifying ways that students could attend school and also support their family at the market. It may be possible for schools to devise methods of providing 'catch up' material to those students who miss lessons. This may also be an issue in those schools that have high absenteeism (e.g. school A3) due to cultural events that may last anywhere from one week to one month. Again, consultation and collaboration with parents and the school community may arrive at a decision acceptable to all. This could include consideration of the length of time children are required to remain at cultural events. It appears that absent students are more likely to be retained. Literature shows that overall, students who are retained are more likely to leave school earlier than those who are promoted (Alexander et al., 2003; Crissom \& Shepard, 1989; Holmes, 2006). Therefore, any possible impact of absenteeism requires investigation. 
Section 2: The role of formative assessment

Discussions in this section are about those findings relating to teacher identification of student learning whether or not teachers use assessment results to inform students' learning and their teaching.

\section{How teachers identify whether their students have or have not understood any given lessons?}

Teachers' responses to this question were grouped into two themes: observations and tests both of which are discussed below.

\section{Observation}

As mentioned in chapter four, two out of six participants from both cases 1 and 2 (Mariana and Ela) used observations to gain an understanding of whether or not their students have understood any given lesson. The focus of their observations was whether or not students appeared to have engaged with the task, yet there was no evidence that students were provided with feedback based on these observations. An observation of students' work is a method to understand students' learning (Harlen \& James, 1997). This method appears most appropriate where teachers have time to observe students, and in those classes with small numbers. However, typical class sizes in the participant schools ranged from 35-58 students and in the case of grade 1, these students were aged six years old. While an observation may be possible with these high numbers of students, any such observation would be superficial. In these large group observations, the teacher tended to give feedback more to the students as 
the whole class rather than to individual students. It would seem that feedback that addresses students as a group may be effective only for the common problems (e.g. the correct place to start writing in an exercise book), but cannot be effective in solving individual student problems. Therefore, feedback for individual student problems is particularly important for grade 1 students who come from a range of backgrounds and experiences and are new to formal education and therefore require a strong foundation for their future learning. Feedback can be used as a means of scaffolding students to reach their potential, as children can learn better under adult guidance, or with their peers, and or with mediating artefacts than what they independently do (Vygotsky, 1978).

While this researcher identified that teachers were using observations as a means of gaining an understanding of whether or not their students have understood any given lesson, this finding is at odds with that of Shah (2011). In his study, Shah identified that after the lesson had been delivered, and while students were working, many teachers often sat at their desk at the front of the classroom. This suggests that teachers did not closely observe students' individual work or give necessary help accordingly.

\section{Tests}

In this study, it appeared that some teachers used regular ongoing testing to gauge student learning. Two out of six participants clearly stated that they discovered whether their students have or have not understood any given lesson through tests that are conducted at the end of every lesson (Celina, case 1, and Lukito, case 2). 
A test that is organised at the end of the lesson appears to be a separated activity that is run after teaching. Such tests appear to be a summative type of assessment. However, if the test results are used for improving students' learning, it is a formative activity (Harlen, 2005).

\section{How the teachers used assessment results?}

The teachers' responses are grouped under the following themes: revising lessons, motivating students, and reporting to the parents.

\section{Revising lessons}

A group of teachers (Celina case 1, and Lukito case 2) stated they used test results for revision of lessons that they planned mainly for those students who received low scores. What these teachers did not make clear is whether or not they modified their teaching when they reviewed a lesson, because the action of revising a lesson does not mean merely reteaching the same lesson with the same methods (Harlen, 2005). As Harlen suggests, it is more effective for learning if revision occurs through different methods or strategies that are a result of teacher reflection of previous teaching methods and strategies. Revising a lesson without revising the teaching methods and strategies would mean that the teacher perceives low test results are due to the students' ability to learn, without consideration of other factors that may include his or her ability to teach. In this study, none of the teachers recognised themselves as a factor that inhibited student learning. This aligns with Shah (2011) who 
found that Timorese teachers believed students' failure to learn was a fault of the students themselves or other factors, rather than any inefficiency in the teacher's own teaching skills. When referring to formative assessment, Hattie (2003) recommends three specific feedback questions: "Where am I going? How am I going? and Where to next?" (p. 2). Given the size of these Timor-Leste classes it would seem almost impossible for a teacher to provide each student which this specific feedback for each curriculum subject. Hattie continues by describing the importance of the feedback in providing information about one's performance. When considering this, one would expect that the Timor-Leste teachers ought to be providing feedback to assists students to improve their performance.

A test given at the end point of a unit of study can be considered as summative assessment and summative tests most often do not provide feedback on how students can improve their performance (Harlen \& James, 1997). Therefore, it is important that the tests or exams given by these Timor-Leste teachers, provide students with feedback that directs them to understand Hattie's (2003) three feedback questions: Where am I going?, How am I going? and Where to next? (p. 2).

\section{Prize giving}

One teacher stated that assessment results were used not only for reporting but also for prize giving to students who received good marks (Rita, case 1). Prize giving for students who receive good marks is a form of extrinsic motivation (Ryan \& Deci, 2000) and ought to encourage the awardees to remain successful in their studies. However, if the prize giving is 
offered in a student assembly, it could strengthen the gap between those who receive prizes and those who did not. While those who receive prizes would feel encouraged to continue to achieve, those who did not receive any prize remain low achievers because they did not get any encouragement.

Another teacher (Amina, case 2) stated that she motivated low achievers by providing them with encouragement.

\section{Reports}

In this study all participants $(n=3)$ from case 1 reported that their students' test results were kept in teacher report books for their own information, and for reporting to the parents. Reporting the students' test results to parents did not necessarily relate to improvement in students' learning as the intention was to inform parents about their children's test results. The report to the parents has little to do with formative assessment because formative assessment is something that should be conducted integrally in teaching, whereas, a report contains the final result of the whole process that ends normally with a summative assessment (Biggs, 2003; Harlen \& James, 1997; Swaffield, 2008).

Observations and tests are techniques relating to formative assessments, and revising a lesson is a follow up action following test results. Thus observation, testing, and revising lessons are activities that can justify that teachers conducted formative assessment as an integral part of their teaching. However, this conclusion diminishes when many of the teachers stated they 
use the tests results for reporting to the parent and, as the basis of providing prize giving to the best students in the class which are not the main objectives of formative assessment.

\section{Section 3: Teachers intervention}

In this section, discussion focuses on the teachers' responses about how they believe they prevent students from being retained in grade 1 . These include exercises requiring students to write words, grouping low achieving students together, giving homework, and replacing the teacher.

\section{Exercise of writing words}

Celina (case 1) explained that following poor test results she paid more attention to the weak students. She did this by holding the student's hand to train them to write on paper and on the blackboard. She perceived that through this action, students would be able to reach the standard to be promoted to grade 2 . Training students to write by holding their hand may be a practical way of teaching how to write an alphabet or draw pictures, but it is not suitable for other skills, for example, reading, speaking, and listening as parts of literacy, and other skills such as Maths. Nevertheless training how to write or read by holding a student's hand is an action that must be done on a one by one basis. In a large class size of up to 58 students, such an intervention may not be effective. This is only possible with a small number of students scheduled at different times. This aligns with another research finding that shows that children learn better in class sizes of under 25 students (Blatchford et al., 2003). After 24 of Celina's students were transferred to a new school, seven of her remaining 34 students failed 
to be promoted due to their inability to write and read. This would support the notion that training students one by one is effective if it involves only a few students and focuses only on a specific skill area. As Celina's students showed, it is less effective - even impossible - to cover a large class size in which every student needs to master different skill areas of the curriculum.

Similarly, Amina (case 2) also commented on her recent experience in giving the exercise of writing words to those students who received low scores. As aforementioned, the exercise of writing words can increase students' skills in drawing alphabets, but is is not suitable for all curriculum areas. Writing words does not involve maths and other subject areas that contribute to learning. Evidence from this study shows that four out of Amina's 53 students failed to gain promotion at the end of 2011, due to their inability to write and read.

\section{Grouping low achieving students together}

Mariana (case 1) explained that in order to prevent students from being retained she paid more attention to those students who had learning problems. She grouped the low achieving students together, separating them from those who achieved better learning outcomes, giving the low achievers priority in the class activities. It would seem logical that this approach may be a practical way for teachers to help struggling students by engaging them more actively in the class. However, grouping them altogether might have a negative effect given that these low achieving students may feel inferior to other students. Furthermore, grouping low achieving students together is odd to Vygotsky (1978) as it might prevent them from learn 
from their peers who have good learning outcomes. In fact, given that ten out of 40 students in Mariana' class failed to be promoted to grade 2, more research evidence needs to be collected to measure whether or not her approach is effective.

\section{Giving low achieving students homework}

Ela (case 2) stated that her intervention to prevent students from grade retention was to give students homework. Homework is a regular task given to the students to improve their learning. Homework can be effective if the parents wish to assist the children by providing a home atmosphere that is conducive to doing homework (Jimerson et al., 2006). Evidence of this study shows that Ela failed seven out of her 35 students, which suggests that giving these students homework did not ensure they were successful. Based on the researcher' own experience and knowledge, the home atmospheres of many families in Timor-Leste are not conducive to learning. Aspects that contribute to poor facilities at home include many children and relatives in a family, poor light or no electricity, all of which make homework more of a challenge and less effective.

Holding a student's hand to write, grouping students and giving them priority in the class activities, exercises of writing words and homework are parts of classroom activities led by the teachers to improve students' learning achievement. Although, these practices have contributed to the students' learning outcomes, they are not the only factor determining the success of students' learning. Classroom conditions and the teacher qualifications share a big part of a student's learning achievement. 


\section{'Replace the teachers'}

Rita (case 1), a teaching-principal explained that she found one grade 1 teacher who had not produced good learning outcomes for her grade 1 students in the previous three years. She therefore decided to transfer the teacher to another grade and placed herself as a teacher for grade 1 . The result was that all her students were promoted with the exception of four underaged students who left earlier for a pre-school, and another one who left the school without notifying the school.

It appears that replacing teachers who do not produce good learning outcomes is one way to challenge teachers to perform as well as possible. How the principal then ensures the new teacher is better than others; where the old teacher is to be deployed to; and, how she or he feels about the new assigned grade, is not clear. Further research needs to address how such a decision might affect teaching and learning.

\section{Section 4: Factors teachers and principals believe inhibit student achievement}

This section discusses teacher and principal participants' beliefs about factors that may have inhibited students' achievement. These include classroom conditions, low teacher qualifications, poor student attendance, and a lack of student interest in learning. Each of these factors is discussed in order to understand how they linked to student achievement and grade retention. 


\section{Classroom conditions}

Classroom conditions in this study are about class sizes, chair-tables for students, and teaching and learning materials.

\section{Class sizes}

Class sizes are defined based on the number of students in a classroom. A small class size consists of less than 20 students, and a large class size consists of 22 or more students (Folmer-Annevelink et al., 2010). In this study, participant class sizes ranged from 35-58 students. These figures align with literature that suggests the classes in the participating schools are large (Blatchford et al., 2003). The participants in this Timor-Leste study identifed that large classes are difficult to manage for effective teaching, and this impacted on student learning, something that is also evidenced in the literature (Blatchford et al., 2003). Teachers in this study suggested that the impact of class size on learning related to the physical space within the classroom. The teachers, including the one who had the smallest class size (35 students) stated that it was difficult to manage the behaviour of 35 , six or seven year old students.

These teachers suggest that class size does affect student learning. The study by Blatchford, et.al., (2003) showed that in the United Kingdom, where teachers are more qualified, a class with 25 students was considered large. The UK study also found that children can learn better in class sizes of under 25 students than in those with over 25 students. 
It seems important that class sizes are reduced in Timor-Leste. As literature shows that class size does impact on learning. Therefore it is reasonable to suggest that lowering class size will impact positively on student outcomes.

\section{Chair-table conditions for students}

Besides overcrowded classes, students are sitting on a chair-table that is designed for only two students, or sitting on the ground. This makes simple tasks such as drawing the alphabet very challenging for the students. For most grade 1 children, holding pencils and pieces of paper to write on is their first formal education experience. Children who are illiterate and learning to write the alphabet, need facilities. This includes having a table to put their papers on when they need to draw letters. Without this facility, learning to draw a standard letter is too difficult for a child.

\section{Teaching-learning materials}

Inadequate learning materials in the classrooms impact on students' learning. Teacher participants suggested that they would like to have textbooks for every grade as had been the practice during the Indonesian occupation when each curriculum subject had a syllabus and a textbook that contained lessons, and a teaching guide. The principal based his experience as a teacher during Indonesia occupation when most Timorese teachers struggled in teaching in 
the class because the language of instruction was new to them with no learning material available for their teaching.

It appears that the suggested text book in addition to syllabuses and teaching guides may not suit other countries. However, for the Timorese context where the language of instruction is new to the teachers, coupled with a lack of adequate learning resources, having a textbook appears to be accepted. The syllabus, the teaching guide and textbook would guide teachers prior to, and during their teaching in the classroom. Without such a package, most teachers will perform poorly, making mistakes in their teaching in the class. As Quinn (2011) found, Timorese teachers often make mistakes in Portuguese while they teach.

As Illeris (2009) identified learning results depend on the capacity of the environment where learning takes place. This suggests that learning depends of the classroom condition as a manipulated environment. Thus a classroom without supporting learning material, learning tends to become monotonous, boring and unattractive to students. Consequently, students cannot achieve their expected outcomes.

\section{Low teacher qualifications}

Three principals raised concerns about teachers' qualifications, stating that they considered low teacher qualification to be a factor that inhibited students' learning outcomes. This concern relating to teacher qualifications is reasonable, given that most teachers have no teaching background. For example, in school B2 seven out of 13 teachers have no teaching 
background nor Portuguese language and their qualification levels are below those described in the Timor-Leste teacher qualification framework (Conselho dos Ministros, 2010). They only have a general secondary certificate. Under the new law teachers are required to master Portuguese and hold a bachelor degree of teaching (Conselho dos Ministros, 2010). Moreover, as mentioned in the findings, an analysis of examination papers confirmed the concern relating to the quality of school assessment, evidenced in teachers' work, the complicated exam instructions, and incorrect marking on students' work.

\section{Low student attendance}

The principal of school A3, case 1 believed that absenteeism inhibited students' learning achievement. Absenteeism related to students being required to work the family stalls at the markets and sometimes due to the timing of traditional Timor-Leste ceremonies. In school B3, case 1 students were often absent from school due to the open market that occurs three different days a week in different villages surrounding the school. As the principal reported, children in his school were asked or even forced by their parents to take the seasonal fruit and vegetables to the markets to get money for their family. This could be a difficult situation for the parents of these students. They must decide whether or not to let their children go to school or, to ask them to go to the market. While they may consider schooling is important, so too is selling the family produce at the market. While schooling lasts the whole year, seasonal harvest fruit and vegetables may last for only a few weeks. As the absenteeism suggests, when faced with this dilemma, many parents opt for the children to take the 
produce to the market otherwise the seasonal foods would become spoiled. After the market they let their children return to school.

Other reasons for low attendance related to the traditional ceremonies of the community. The same principal reported that children were absent from school to participate together with their parents in ceremonies that often last for weeks and even up to a month at a time.

Being absent from school means students lose the opportunity to learn the knowledge or skills that might have been planned for the day. Learning is easier for those who learn a new element with their previous learnt knowledge or skill (Illeris, 2009). It is reasonable to assume that absent students would lag behind those students who have not been absent. As the students fall behind, it is likely they lose their motivation to learn, which could result in them be retained or leaving school altogether.

Whether or not children need to stay for the whole of the ceremonial activities that may last up to a month requires further research. Also requiring further research is the impact of such prolonged absences on the students' future schooling.

\section{Lack of learning interest}

As mentioned, two teachers from case 1 and one from case 2 reported that some of their students were not interested in learning. These teachers perceived that children went to school because they were pushed by their parent and this often meant that children did not want to learn. Future research could address the reasons why some students in these schools are not 
interested in learning. However, a lack of interest in learning may be well related to classroom situations such as those already described: overcrowded classrooms, students sitting on the ground, a lack of supporting material and low teacher qualifications. As Illeris (2009) argues, learning begins with the interaction between the individual and the environment, and the result of learning depending on the possibility that is influenced by the conditions of learning whether or not students are interested (Illeris, 2009).

\section{No pre-school experience}

A teaching principal relates poor learning outcomes to students' enrolment that most grade 1 students had no pre-school education, and that grade 1 is their first experience of a formal education. Preschool in the Timor-Leste education system is not compulsory (Parlamento Nacional, 2008).

It appears that teaching in grade 1 is challenging as most students have no pre-school experience, yet many of them are from low economic backgrounds. It is important that these children having a pre-school education before experiencing academic challenges. Literature in this study shows that a pre-school intervention programme aims to assist at-risk students before they experience academic challenges through enhancing foundation skills necessary for subsequent academic success (Ziggler \& Styfco, 2000). 
Section 5: Teachers' and principals' beliefs about grade retention

This last section discusses teachers and principals' beliefs about grade retention. As indicated in the findings, academic performance of the students before and after grade retention influences teachers' decisions about whether or not to hold back a student. The discussion, therefore, focuses on poor academic performance of the students before grade retention, and better learning after this action. This section ends with the teachers' views on the grade retention.

\section{Poor academic performance}

In this study all participants $(\mathrm{N}=10)$ believed that the reason for grade retention was because students had gained a score below the promotional standard, 42 out of a possible 70 points in the end of year exams. The exam reports from three schools also show students who were retained at the end of grade 1 had gained less than 42 points.

It appears that academic performance is regarded as the main reason teachers retain or promote a student. This aligns with findings from the United State of America that most grade retention decisions were made due to the poor academic performance of the students (Bali et al., 2005; Witmer et al., 2004). However, as mentioned in section 1, beside academic performance, non-academic performance such as students' attendance and attitudes are also involved in grade retention or promotion decisions in the participating schools. Analysis of exam documents shows that a student who achieved 43 points was also retained. Academically the student met the promotional requirement. The student was possibly 
retained due to his or her attendance or negative attitude towards the school although there was no evidence to justify this argument.

\section{Better learning outcomes}

All participants $(\mathrm{N}=10)$ believe grade retention leads to better learning outcomes. They consistently asserted that their students achieved better learning outcomes after being retained. They strongly argued that the repeaters achieved their best performance after retention. Some of them even reached the first ranks in the class, as evidenced in the teachers' comments. Teachers' claims that grade retention leads to better learning outcomes of the learners is supported by evidence from school A2, case 2. Although students' reports had been distributed without copies being made and kept at the school, it was possible to obtain a copy of one child's report through a request to the parents. Perusal of this report showed that the student failed to get promotion in the previous year with a score of 41 for the seven subjects taught at grade 1, but his score after retention reached 50 out of a possible of 70 points. Other evidence included a list of students' Portuguese and Maths national tests. The list indicated three students who repeated grade 6 in school A1, case 1 had the highest score of Portuguese and Maths in a national test.

It appears that this belief is likely to have influenced teachers to retain students who received low scores in the end of year exam. This suggestion aligns with those (Nisbett \& Ross, 1980; Bandura, 1986) who argued that beliefs are the best indicators of the decisions individuals make throughout their lives (Pajares, 1992). Witmer et al., (2004) found that beliefs and 
perceptions about the benefit of grade retention influenced teachers to retain students with low academic performance. Consequently teachers continue to hold back students with low academic performance. This particular inference aligns with Schnurr, Kundert, and Nickerson (2009) who found that in USA grade retention continues to be used as an intervention for struggling students.

The finding that grade retention leads to better learning outcomes differs from those of the previous research. Meisels and Liaw (1993) found that most of those students who were held back a year did not have improvement in their learning outcomes after retention. Further, Roderick and Nagaoka (2005) found students who were retained under Chicago's high stakes testing programme from 1997-2000 continued to struggle during their retained year. The beliefs that grade retention leads to a better learning outcomes of the repeaters may be linked to the teachers' argument that they specifically pay attention and provide encouragement to the repeaters in order to change their learning attitudes.

It appears that due to the schools' limitations, teachers cannot provide adequate intervention to prevent students from being retained, while there is a hope that the struggling students can come back for the same grade to master their learning the following year. Some teachers appeared to pay more attention to students who had been retained and motivated them to learn than those who are new to the grade. Such an approach may be worthwhile for those who do come back to repeat their studies, but it is too late for those failing students who feel frustrated and leave the school forever. As it was identified that the vast majority of students 
who dropped out do so in grade 1 or 2 (MoE, 2010a), it is possible that some of them were those who failed in grade 1 . Further research is necessary to prove how teachers motivate new students as compared to the repeaters.

\section{Teachers' views about grade retention}

Most participating teachers and principals $(n=7)$ responded negatively when asked if grade retention ought to be abolished. They argued that grade retention is a good practice for those students who do not master lessons in their first year. They worried about the quality of education if all children are to be promoted. It appears that these participating teachers and principals do not have academic knowledge about grade retention. Schnurr, Kundert and Nickerson (2009) found that grade retention rates were lower in schools where school psychologists were involved in the grade retention decision. Similarly, principals who have knowledge of grade retention reduced the number of students who were supposed to be retained because they understood the negative impacts on students (Larsen \& Akmal, 2007).

It is important that teachers and principals have knowledge about grade retention and its negative effects on children. Therefore, teacher training material which includes academic evidences of grade retention would encourage teachers to make a fair decision regarding student learning. 


\section{Summary of discussions and conclusion}

\section{Grade retention practices}

As the findings in this study have shown, grade retention has been practised at grade 1 in all participating schools and students are retained or promoted based on various teacherperceptions of acceptable content for an exam that is graded as a pass or a fail. As grade retention tends to push students to drop out earlier from school before completing a level (Alexander et al., 2003) it is important that the criteria used to promote or retain students is standardised across and within schools. Such inconsistency in the promotion and retention of students should end with a written policy that addresses uniformity of the system.

\section{The use of formative assessment}

It is less evident in this study that regardless of the methods of assessment teachers perceive they use (for example, observation or tests) they do not provide feedback to students to inform their learning. These participating teachers also do not conduct planned formative assessment that research has shown, improves student learning outcomes (Harlen, 2005; Hattie, 2009). It is important that teachers conduct formative assessment to inform how students learnt and how their teaching strategies were. Teachers' teaching strategies need to be changed if learning outcomes are low. 


\section{Teaching interventions}

The teachers did not introduce specific teaching interventions such as school breaks or after school intervention programmes for low achieving students. These teachers reported that they instead paid more attention to low achieving students to improve their learning. The ways in which these teachers paid attention to at-risk students differed, ranging from grouping low achieving students altogether, 'training students' to write or draw words, replacing the teachers, homework, and reviewing the lessons. These methods may improve students' learning, but there was little evidence that they are an effective means of preventing students from being retained.

\section{Factors inhibit students' learning}

Aspects of a classroom such as overcrowding, insufficient chair-tables for students, lack of supporting material, and low teacher qualifications are factors that likely inhibit student learning. Despite having these limitations schools continue to retain low achieving students.

It is important that the classroom conditions are improved and teachers' qualifications are upgraded to improve students' learning and coincidently reduce grade retention.

\section{Teachers' beliefs}

The participating teachers believe grade retention leads to better learning outcomes. This belief differs from those of the previous research, for example Meisels and Liaw (1993) found that most of those students who were held back a year did not have improvement in 
their learning outcomes after retention. The beliefs of the participating teachers combined with their lack of knowledge about grade retention, led them to continue to hold back students. It is important that these teachers have knowledge about grade retention with the aim of reducing grade retention.

This chapter has presented discussion about the findings by using literature relating to grade retention and suggests improvement to the education system in Timor-Leste.

The following chapter presents recommendations that aim to improve students' learning and reducing grade retention rates. 


\section{Chapter 6: Recommendations}

This study has identified some issues relating to the promotion or retention of grade 1 students in six Timor-Leste schools. Clearly, data from these findings suggest further research is required across a number of areas including improving classroom conditions and increasing teacher pedagogical knowledge to include the use of evidence. This study has also identified a lack of consistency between schools in relation to grade retention practices.

Grade retention has been identified as one of the concerns relating to the Timor-Leste Ministry of Education programme that aims to improve the access to quality education for all Timorese children (MoE, 2010a).

This study has not only identified issues, but also provides suggested recommendations with initial steps to support the Timor-Leste Ministry of Education to improve overall quality of grade 1 education. For this purpose the researcher offers the recommendations as shown in table 21: 
Table 21: Recommendations

\begin{tabular}{|c|c|c|}
\hline Key finding & Recommendation & Suggested next steps \\
\hline \multirow[t]{2}{*}{$\begin{array}{l}\text { Inconsistency in } \\
\text { grade } \\
\text { promotion- } \\
\text { retention } \\
\text { criteria }\end{array}$} & $\begin{array}{l}\text { Standardise criteria } \\
\text { for promotion of } \\
\text { grade } 1 \text { students }\end{array}$ & $\begin{array}{l}\text {-Set up a national guide for promotion or retention of grade } \\
1 \text { students; } \\
\text {-Disseminate the grade retention guide to teachers, } \\
\text { principals, inspectors, school administrators and parents }\end{array}$ \\
\hline & $\begin{array}{l}\text { Standardise } \\
\text { examination criteria }\end{array}$ & $\begin{array}{l}\text {-Set up a national standard for grade } 1 \text { examinations; } \\
\text {-Apply moderation procedures in examinations to prevent } \\
\text { inconsistency, teacher errors, and subjective judgements; } \\
\text {-Change the quantitative judgement report to a qualitative } \\
\text { report to provide clear information about what has been } \\
\text { achieved. }\end{array}$ \\
\hline $\begin{array}{l}\text { Unclear } \\
\text { understanding } \\
\text { of the role of } \\
\text { formative } \\
\text { assessments }\end{array}$ & $\begin{array}{l}\text { Promote and } \\
\text { integrate formative } \\
\text { assessments in } \\
\text { teaching }\end{array}$ & $\begin{array}{l}\text {-Develop material regarding formative assessment; } \\
\text {-Organise teacher training regarding how to apply } \\
\text { formative assessment, and how to use tests results; } \\
\text {-Involve children in establishing their learning goals } \\
\text {-Provide feedback for learning to students }\end{array}$ \\
\hline $\begin{array}{l}\text { Little evidence } \\
\text { of effective } \\
\text { intervention to } \\
\text { reverse grade } \\
\text { retention }\end{array}$ & $\begin{array}{l}\text { Design and develop } \\
\text { specific intervention } \\
\text { programmes for low } \\
\text { achieving students }\end{array}$ & $\begin{array}{l}\text {-Design a specific intervention programme for low } \\
\text { achieving students; -Organise teacher training for } \\
\text { implementation of the intervention programme; } \\
\text {-Piloting the intervention programme; -Implement the } \\
\text { intervention programme for schools in needs }\end{array}$ \\
\hline $\begin{array}{l}\text { Large class } \\
\text { sizes and poor } \\
\text { classroom } \\
\text { conditions }\end{array}$ & $\begin{array}{l}\text { Promote a conducive } \\
\text { classroom for } \\
\text { learning }\end{array}$ & $\begin{array}{l}\text {-Determine a national standard of class size; } \\
\text {-Lowering class size by not enrolling underage students; } \\
\text {-Design and purchase appropriate chair-tables for grade } 1 \\
\text { students }\end{array}$ \\
\hline $\begin{array}{l}\text { Lack of } \\
\text { learning } \\
\text { material }\end{array}$ & $\begin{array}{l}\text { Design a specific } \\
\text { curriculum for grade } \\
1 \text { students }\end{array}$ & $\begin{array}{l}\text {-Review the existing curriculum for grade } 1 \text {; } \\
\text {-Develop a teaching guide in simple language for teachers; } \\
\text {-Develop basic materials for literacy and numeracy from } \\
\text { different subject for students; } \\
\text {-Provide teacher professional development in the use of } \\
\text { reading materials including differentiation practices }\end{array}$ \\
\hline $\begin{array}{l}\text { Unqualified } \\
\text { teachers } \\
\text { teaching in } \\
\text { schools }\end{array}$ & $\begin{array}{l}\text { Develop professional } \\
\text { grade } 1 \text { teachers }\end{array}$ & $\begin{array}{l}\text {-Provide professional development to familiarise teachers } \\
\text { with grade } 1 \text { curriculum and its implementation; } \\
\text {-Develop pedagogical skills for teachers; } \\
\text {-Provide professional development for teachers that } \\
\text { includes the use of evidence in classroom practice, and } \\
\text { particularly in decisions around grade retention; } \\
\text {-Review the role of volunteer teachers }\end{array}$ \\
\hline
\end{tabular}


Finally, this study has identified a number of key areas that require further, sustained focus to improve current practice. With Ministry support, it ought to be possible to move forward with practices that not only support teachers in making evidence-based decisions to promote or retain students, but also in creating classrooms that engender student learning. In these classrooms where students play an active role in determining goals for their learning, they can actively engage in learning processes towards achieving better learning outcomes. Thus a better learning outcome could increase grade promotion rates, and at the same time reduce grade retention and its negative impacts on children, their learning and education resources. 


\section{List of references}

Alderman, M. K. (1999). Motivation for achievement: Possibilities for teaching and learning. Mahwah: Lawrence Erlbaum Associates, Inc.

Alexander, K. L., Entwisle, D. R., \& Dauber, S. L. (2003). On the success of failure. A reassessment of the effects of retention in the primary school grades (2nd. ed., Vol. 1). Cambridge: The press syndicate of the University of Cambridge.

Anderson, G. E., Jimerson, S. R., \& Whipple, A. D. (2005). Student ratings of stressful experiences at home and school: Loss of a parent and grade retention as superlative stressors. [Article]. Journal of Applied School Psychology, 21(1), 1-20. doi: 10.1300/J008v21n01_01

Bali, V. A., Anagnostopoulos, D., \& Robert, R. (2005). Toward a political explanation of grade retention. Educational Evaluation and Policy Analysis, 27(2), 155.

Bandura, A. (1989). Human agency in social cognitive theory. [Article]. American Psychologist, 44(9), 1175-1184.

Bee, H., \& Boyd, D. (2007). The developing child (11th ed.). Boston: Pearson.

Berg, B. L. (2004). Qualitative research methods for the social science (5th ed.). Boston: Pearson Education.

Biggs, J. (2003). Assessing for learning quality 1: principles Teaching for quality learning at university (2ed ed., pp. 140-169). Maidenhead, England: Society for research into higher education and open university press.

Blatchford, P., Bassett, P., Goldstein, H., \& Martin, C. (2003). Are class size differences related to pupils' educational progress and classroom processes? Findings from the 
institute of education class size study of children aged 5-7 years. British Educational Research Journal, 29(5), 709.

Bramlett, R., Cates, G. L., Savia, E., \& Lauinger, B. (2009). Assessing effectiveness and efficiency of academic intervention in school psychology journals: 1995-2005. Psychology in the Schools, 47(2), 114-125. Retrieved from Wiley InterScience website: www.interscience.wiley.com doi:10.1002/pits.20457

Conselho dos Ministros. (2010). Estatuto da Carreira dos Educadores de Infancia e dos Professores do Ensino Basico e secundario. Dili, Republica Democratica de TimorLeste: Journal da Republica.

Creswell, J. W. (2009). Research design: Qualitative, quantitative, and mixed methods approaches. Thousand Oaks, California: Sage Publications, Inc.

Crissom, J. B., \& Shepard, L. A. (1989). Repeating and dropout of school. In L. A. Shepard \& M. L. Smith (Eds.), Flunking grades. London: The Palmer Press.

Denscombe, M. (2010). Ground rules for social research: guidelines for good practice (2nd ed.). New York: Open University Press.

Denton, C. A., Solari, E. J., Ciancio, D. J., Hecht, S. A., \& Swank, P. R. (2010). A pilot study of a kindergarten summer school reading program in high-poverty urban schools. Elementary School Journal, 110(4), 423-439.

Dweck, C. S., \& Master, A. (2008). Self-theories and self-regulated learning. In D. H. Schunk \& B. J. Zimmerman (Eds.), Motivation and self-regulated learning: Theory, research and applications (pp. 31-52). New York: Lawrence Erlbaum Associates. 
Engestrom, Y. (1987). Expansive learning. In K. Illeris (Ed.), Contemporary theorists of learning. London and New York: Routledge.

Folmer-Annevelink, E., Doolaard, S., Mascareño, M., \& Bosker, R. J. (2010). Class size effects on the number and types of student-teacher interactions in primary classrooms. [Article]. Journal of Classroom Interaction, 45(2), 30-38.

Gardner, H. (2009). Multiple approaches to understanding. In K. Illeris (Ed.), Contemporary theories of learning (pp. 106-115). London: Routledge.

Geason, K. A., Kwok, O. M., \& Hughes, J. N. (2007). The short term effect of grade retention on peer relation and academic performance of at-risk first graders. The Elementary School Journal, 327-340.

Graue, E., Rauscher, E., \& Sherfinski, M. (2009). The Synergy of Class Size Reduction and Classroom Quality. The Elementary School Journal, 110(2), 202.

Guevremont, A., Roos, N. P., \& Brownell, M. (2007). Predictors and consequences of grade retention. Canadian Journal of School Psychology, 22(1), 50-60. Retrieved from Sage Publications website: http://www.sagepublications.com

Harlen, W. (2005). Teachers' summative practices and assessment for learning - tensions and synergies. The curriculum journal, 16(2), 207-233. Retrieved from

Harlen, W., \& James, M. (1997). Assessment and learning: Differences and relationships. Assessment in Education: Principles, Policy \& Practice, 4(3), 365.

Hattie, J. (2003). Formative and summative interpretation of assessment information. In J. Hattie (Ed.), (Vol. 1, pp. 1-9). Auckland School of Education The University of Auckland, Auckland, New Zealand. 
Hattie, J. (2005). What is the nature of evidence that makes a difference to learning? Australian Council for Educational Research. Retrieved from research.acer.edu.au/research_conference_2005/7

Hattie, J. (2009). Visible learning: A synthesis of over 800 meta-analyses relating to achievement: Routledge.

Hattie, J., \& Timperley, H. (2007). The power of feedback. [Article]. Review of Educational Research, 77(1), 81-112. doi: 10.3102/003465430298487

Heron, J. (1992). Life cycles and learning cycles. In K. Illeirs (Ed.), Contemporary theories of learning: Learning theorists...in their own words (pp. 129-146). London and New York: Routledge.

Holmes, C. T. (2006). Low test scores + high retention rates $=$ more dropouts Kappa Delta Pi Record, 42(2), 58.

Hong, G., \& Yu, B. (2007). Early-grade retention and children's reading and maths learning in elementary years. Educational Evaluation and Policy Analysis, 29(4), 239-261. Retrieved from hhtp://eepa.aera.net doi:10.3102/0162373707309073

Hudley, C., \& Gottfried, A. E. (2008). Academic motivation and the culture of school in childhood and adolescence (Vol. 1). New York: Oxford University Press.

Illeris, K. (2009). A comprehensive understanding of human learning. In K. Illeris (Ed.), Contemporary theories of learning. Learning theorists...in their own words (pp. 7-20). London and New York: Routledge. 
James, M. (2008). Assessment and learning. In S. Swaffield (Ed.), Unlocking assessment: Understanding for reflection and application (pp. 21-35). London and New York: Routledge.

Jimerson, S. R. (2001). Meta-analysis of grade retention research: Implications for practice in the 21st century. School Psychology Review, 30(3), 420-437.

Jimerson, S. R. (2004). Is grade retention educational malpractice? Empirical evidence from meta-analysis examing the efficacy of grade retention. In H. J. Walberg, A. J. reynelds \& M. C. Wang (Eds.), Can unlike students learn together?: grade retention, tracking, and grouping (pp. 71-96). Greenwich: CO International Age Publishing.

Jimerson, S. R., Anderson, G. E., \& Whipple, A. D. (2002). Winning the battle and losing the war: Examining the relation between grade retention and dropping out of high school. Psychology in the schools, 39(4), 441-457.

Jimerson, S. R., Ferguson, P., Whipple, A. D., Anderson, G. E., \& Dalton, M. J. (2002). Exploring the association between grade retention and drop out: A longitudinal study examing socio-emotional, behaviour, and achievement characteristic of retained students. The Califonia School Psychologist, 7, 51-62.

Jimerson, S. R., Pletcher, S. M. W., Graydon, K., Schnurr, B. L., Nickerson, A. B., \& Kunder, D. K. (2006). Beyond grade retention and social promotion: Promoting the social and academic competence of students. Psychology in the Schools, 4(1). Retrieved from Wiley Periodicals website: doi:10.1002/pits.20132

Johnson, B., \& Christensen, L. (2008). Educational research: Quantitative, qualitative, and mixed approaches (3rd ed. Vol. 1). Thousand Oaks: Sage Publications. 
Jorgensen, R., Grootenboer, P., Niesche, R., \& Lerman, S. (2010). Challenges for teacher education: The mismatch between beliefs and practice in remote Indigenous contexts. Asia-Pacific Journal of Teacher Education, 38(2), 161-175. doi: $10.1080 / 13598661003677580$

Klenowski, V., \& Wyatt, C. (2010). Standards, teacher judgement and moderation in contexts of national curriculum and assessment report. Assessment Matters, 2, 107-131. Retrieved from http://eprints.qut.edu.au

Larsen, D. E., \& Akmal, T. T. (2007). Making decision in the dark: Disconnects between retention research and middle level practice. NASSP bulletin, 91(1), 33-53.

Martin, A. J. (2011). Holding back and holding behind: Grade retention and students' non academic and academic outcomes. Bristish Educational Research Journal, 37(5), 739-763.

Maxwell, G. (2007). Implications for moderation of proposed changes to senoir secondary school syllabuses Brisbane: Queensland Studies Authority.

McInerney, D. M., \& McInerney, V. (2006). Educational psycology: Constructing learning (4th ed. Vol. 1): Pearson Education Australia.

Meisels, S. J., \& Liaw, F. R. (1993). Failure in grade: Do retained students catch up? The Journal of Educational Research, 69-77.

Mezirow, J. (1978). An overview on Transformative Learining. In K. Illeris (Ed.), Contemporary theories of learning: Learning theorists...in their own words (pp. 90105). London and New York: Routledge. 
MoE. (2005a). Programa língua portuguesa ensino primário 1-6 ano. Dili, Repubica

Democratica de Timor-Leste: Ministério da Educação.

MoE. (2005b). Programa matemática ensino primário 1-6 ano. Dili, Republica Democratica de Timor-Leste: Ministério da Educação.

MoE. (2006). Plano curricular para o ensino primario. Dili, Republica Democratica de Timor-Leste: Ministério da Educação e da Cultura.

MoE. (2009). Calendario escolar do ano lectivo 2010. Dili, Republica Democratica de Timor-Leste: Ministério da Educação.

MoE. (2010a). Basic Education Strategic Plan. Dili: Ministry of Education of Democratic Republic of Timor-Leste.

MoE. (2010b). Legal regime for administering and managing the basic education system.

Dili, Democratic Republic of Timor-Leste: Mnistry of Education.

MoE. (2010c). Manual de Exame Nacional Ano Escolar 2010. Dili, Republica Democratica de Timor-Leste: Ministério da Educação.

Nakamura, J., \& Csikszentmimalyi. (1989). The concept of flow. Retrieved from mywebstewards.ed/michaelo

Nason, R. B. (1991). Retaining children. Childhood Education, 67(5), 300.

Ndarahutse, S. (2008). Grade repetition in primary schools in Sub-Saharan Africa: An evidence base for change. The United Kingdom: CfBT Education Trust.

NZARE. (2010). New Zealand Association for Research in Education Ethical Guidelines 2010. Retrieved from http://www.nzare.org.nz/pdfs/ 
Owings, W. A., \& Kaplan, L. S. (2001). Alternatives to retention and social promotion. Bloomington, Indiana: Phi Delta Kappa Educational Foundation.

Pajares, M. F. (1992). Teachers' beliefs and educational research: Cleaning up a messy construct. Review of Educational Research, 62(3), 307.

Parlamento Nacional. (2008). Lei bases da educação. Dili, Democratic Republic of TimorLeste: Journal da Republica.

Patton, M. (2002). Qualitative research and evaluation methods (3rd ed.). California: Sage Publications.

Quinn, M. (2011). Language of schooling in Timor-Leste: Pattern and influences on practice (unplublished). (Ph.D), The University of Melbourne.

Roderick, M., \& Nagaoka, J. (2005). Retention under Chicago's high stakes testing program: Helpful, harmful, or harmless. Education Evaluation and Policy Analysis, 27(4), 309340.

Ryan, R. M., \& Deci, E. L. (2000). Intrinsic and extrinsic motivations: Classic fefinitions and new directions. Contemporary Educational Psychology, 25(1), 54-67. doi: 10.1006/ceps. 1999.1020

Schnurr, B. L., Kundert, D. K., \& Nickerson, A. B. (2009). Grade retention practice: Current decision-making practices and involvement of school psychologists working in public schools. Psychology in the Schools, 46(15), 410-419.

Shah, R. (2011). Perceptions, practices, and policies about teaching and learning in TimorLeste: A paper discussing findings and implications from a study from a primary teachers' attitudes and actions. Wellington: New Zealand Aid Programme. 
Swaffield, S. (2008). Unlocking assessment: Understanding for reflection and application. London adn New York: Routledge.

Temple, J. A., Reynolds, A. J., \& Miedel, W. T. (1998). Can early intervention prevent high school dropout? Evidence from Chicago Child-Parent Centers. Paper presented at the 4th Head Start Research Conference, Washington, DC.

Temple, J. A., Reynolds, A. J., \& Ou, S.-R. (2004). Grade retention and school dropout: another look at evidence. In H. J. Welberg, A. J. Reynolds \& M. C. Wang (Eds.), Can unlike students learn together? Grade retention, tracking and grouping (pp. 35-70). Greewich: CO, Information Age Publishing.

The World Bank. (2004). Timor-Leste: Education since independence from reconstruction to sustainable development (pp. 1-33). Dili: The World Bank.

Usher, R. (2009). Experience, pedagogy, and social practices. In K. Illeris (Ed.), Contemporary theories of learning: Learning theorists...in their own words (pp. 169183). London and New York: Routledge.

Vygotsky, L. S. (1978). Interaction between learning and development. In M. Gauvain \& M. Cole (Eds.), Reading on the development of children (2nd ed., pp. 29-36). New York: W. H. Freeman and Company.

Witmer, S. M., Hoffman, L. M., \& Nottis, K. E. (2004). Elementary teachers' beliefs and knowledge abaout grade retention: How do we know what they know. Education, 125(2), 173-187. 
Wyatt-Smith, C., Klenowski, V., \& Gunn, S. (2010). The centrality of teacher's judgement practice in assessment: A study of standards in moderation. Assessment in Education: Principle, Policy \& Practice, 17, 75-75.

Wynn, J. L. (2010). A study of selected teachers' perceptions of grade retention in a Florida school district. (Doctor of Education Thesis and Dissertations), University of South Florida. (6-1-2010)

Yin, R. K. (2003). Appreciations of case study research (2nd ed. Vol. 34). Thousand Oaks, London and New Delhi: Sage Publications.

Ziehe, T. (2009). 'Normal learning problem' in youth: In the context of underlying cultural convictions. In K. Illeris (Ed.), Contemporary theories of learning: Learning theorists...in their own words (pp. 184-199). London and New York: Routledge.

Ziggler, E., \& Styfco, S. J. (2000). Pionering steps (and fumbles) in developing a federal preschool intervention. Topics in early childhood education. Journal of Reproduction Services, 20, 67-70. 


\section{Appendices}

\section{Appendix A: Data collection timelines}

\begin{tabular}{|c|c|c|c|c|c|c|c|c|c|c|c|c|}
\hline \multirow[t]{2}{*}{ Steps } & \multirow[t]{2}{*}{ Data collection activities } & \multicolumn{3}{|c|}{ Nov.2011 } & \multicolumn{4}{|c|}{ Dec. 2011} & \multicolumn{4}{|c|}{ Jan 2012} \\
\hline & & II & III & IV & $\mathbf{I}$ & II & III & IV & $\mathbf{I}$ & II & III & IV \\
\hline 1 & $\begin{array}{l}\text { Receive ethical approval from VUW Human } \\
\text { Ethics Committee }\end{array}$ & & & & & & & & & & & \\
\hline 2 & Travel to Timor-Leste & & & & & & & & & & & \\
\hline 3 & $\begin{array}{l}\text { Visit and approach Minister/ Directors of } \\
\text { Ministry of Education of Timor-Leste }\end{array}$ & & & & & & & & & & & \\
\hline 4 & $\begin{array}{l}\text { Select two districts and communicate to the } \\
\text { selected district directors about the research, } \\
\text { seeking permission to conduct my research } \\
\text { in their districts }\end{array}$ & & & & & & & & & & & \\
\hline 5 & $\begin{array}{l}\text { Approach the schools of the first selected } \\
\text { districts to ask the principals to allow } \\
\text { researcher conduct the study }\end{array}$ & & & & & & & & & & & \\
\hline 6 & $\begin{array}{l}\text { Meeting with grade } 1 \text { teacher to explain the } \\
\text { study and making appointment for interview }\end{array}$ & & & & & & & & & & & \\
\hline 7 & Interview the teachers and study documents & & & & & & & & & & & \\
\hline 8 & $\begin{array}{l}\text { Interview the principals and study } \\
\text { documents }\end{array}$ & & & & & & & & & & & \\
\hline 9 & $\begin{array}{l}\text { Repeat activities } 5-8 \text { for the two other } \\
\text { schools }\end{array}$ & & & & & & & & & & & \\
\hline 10 & $\begin{array}{l}\text { Transcribe interviews of the first three } \\
\text { schools (three teachers and three } \\
\text { participants) }\end{array}$ & & & & & & & & & & & \\
\hline 11 & $\begin{array}{l}\text { Write down a summary and bring back to } \\
\text { each participant for confirmation. }\end{array}$ & & & & & & & & & & & \\
\hline 12 & $\begin{array}{l}\text { Repeat the number 5-11 activities for the } \\
\text { second selected district }\end{array}$ & & & & & & & & & & & \\
\hline 13 & Study and collect documents at the MoE & & & & & & & & & & & \\
\hline 14 & $\begin{array}{l}\text { Translations from the interview language } \\
\text { into English }\end{array}$ & & & & & & & & & & & \\
\hline 15 & Travel back to New Zealand & & & & & & & & & & & \\
\hline
\end{tabular}




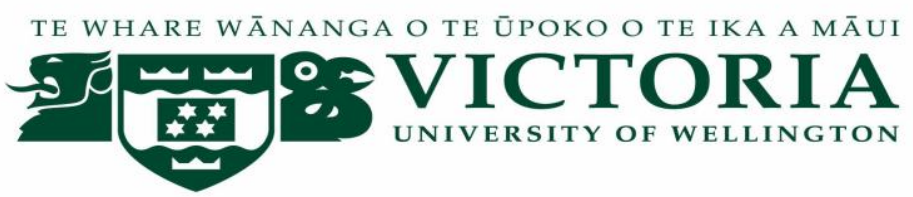

\title{
Appendix B: Director General of School Administration, Innovation and Curriculum Development (SAICD)
}

\author{
Project Title \\ Primary Teachers' Beliefs and Practices in relation to Grade Retention in Timor-Leste \\ Dear Director General of School Administration, Innovation and Curriculum Development
}

My name is Cidalio Leite and I am conducting research as part of my Masters of Education Thesis for the School of Psychology and Pedagogy, Faculty of Education at Victoria University of Wellington. I would like to request your approval to interview three school principals and three grade 1 teachers about: their beliefs and practices in relation to Grade Promotion-Retention; Criteria and mechanisms he/she uses to promote-retain students; the role of assessments; and strategies, if any, that he/she uses to prevent student from retention. These interviews would take place between 21 November and 14 January 2012. In addition I wish to review school records that provide data relating to the number of students who have been retained in the previous two years.

The aim of the research project

The purpose of the research is to better understand Grade 1 teachers' beliefs and practices, and the principals' role in relation to grade retention in their school.

\section{Project Procedures}

The interview will be conducted at an agreed upon date, time and place between the participant and researcher. The researcher will endeavour to accommodate the participant regarding these details as best possible.

The interview will take approximately 45 minutes to an hour for each participant. As per the signed consent form, the interview will be audio tape-recorded with the permission of the participants. If a 
participant requests that the tape recording cease, that wish will be respected. The interview will be transcribed by the researcher and transcripts will be made available to the interviewed participants.

\section{Data Storage/Retention/Destruction/Future Use}

The gathered data will be collated from answers given in the interviews and responses will be written /recorded and transcribed by the researcher. A tape recorder will be used with the consent of the participant. The data will be used only for this research and will be stored in a locked cabinet in Victoria University of Wellington. Access to the data will be limited to myself and my academic supervisor. All data and materials will be destroyed after three years.

\section{Right to Withdraw from Participation}

Participants have the right to withdraw from the project at any time, and to withdraw any data contributed by them up till $10^{\text {th }}$ January 2012. On completion of this study, all participants will receive a summary of findings. The participant may request to have the voice recorder turned off at any time. Contact with the researcher must be made by the teacher participant via phone or e-mail prior to this date.

\section{Anonymity and Confidentiality}

As per the signed consent form, code names will be used to ensure that the identities of participants and the information they disclose remain anonymous

\section{The approval of the project}

This project has been approved by the Victoria University Faculty of Education Ethics Committee.

\section{Contact Details:}

\begin{tabular}{|l|l|l|}
\hline Student researcher & Supervisor & Director \\
\hline Cidalio Leite & Dr. Jenny Horsley & Dr. Lex McDonald \\
School of Education Psychology and & School of Education Psychology & School of Education \\
Pedagogy, Faculty of & and Pedagogy, Faculty of & Psychology and Pedagogy, \\
Education,Victoria University of & Education, & Faculty of Education, \\
Wellington & Victoria University of & Victoria University of \\
33 Campbell St, Karori, Wellington & Wellington. & Wellington. Campbell St. \\
6172, NZ & Campbell St, Karori, Wellington & Karori, Wellington 6172, \\
Telephone in New Zealand: & 6172, & New Zealand \\
\hline
\end{tabular}




\begin{tabular}{|l|l|l|}
\hline+640220140358 & New Zealand & Telp: +64 4635173 \\
Telp in Timor-Leste: & Telp:+64 4639704 & E-mail: \\
+670-7254151 & E-mail: & lexmcdonald@ vuw.ac.nz \\
E-mail: leitecida@myvuw.ac.nz & Jenny.Horsley@vuw.ac.nz & \\
\hline
\end{tabular}

For any queries regarding ethical concerns you may contact the Chair, Victoria University of Wellington Human Ethics Committee, Dr. Allison Kirkman: Allison.Kirkman@vuw.ac.nz.

Yours Sincerely

Cidalio Leite

Master of Education Candidate (Student ID 300196535)

School of Education Psychology and Pedagogy

Faculty of Education

Victoria University of Wellington

This research has been assessed and approved by Victoria University of Wellington Faculty of Education Ethics Committee, proposal number SEPP/74/18896. 


\section{Appendix C: Director General of SAICD's Consent Form}

Project Title: Primary Teachers' Beliefs and Practices in relation to Grade Retention in Timor-Leste

Name of Researcher: Cidalio Leite (Student ID: 300196535)

I have read the Participant Information Sheet and understand the nature of the research and why my district has been selected. I have had the opportunity to ask questions and have had them answered to my satisfaction.

I agree for my school principals and teachers to be interviewed as part of this research.

$\square$ I understand that principals and teachers' participation in this study is entirely voluntary.

$\square$ I understand that principals and teachers are free to end their participation at any time, and to withdraw any data traceable to them up until 10 January 2012

$\square$ I understand that principals and teachers will be audio-taped on consent, and that the tapes and transcripts will not be made available to any superiors of the school principals including myself

$\square$ I understand that the transcripts of interviews will be translated into English by the researcher

$\square$ I understand that principals and teachers can request to stop the recording at any time.

$\square$ I understand the researcher will ensure the confidentiality of the principals and teachers at all times.

$\square$ I understand that the data will be kept for 3 years, after which it will be destroyed.

$\square$ I understand that the principals and teachers will be fully informed of the nature of this research and be required to give signed consent.

$\square$ I understand that the names and identities of participants and teachers and the names of their schools and communities will not be identified in the research. 
Name:

Signature: Date:

This research has been assessed and approved by Victoria University of Wellington Faculty of Education Ethics Committee, proposal number SEPP/74/18896.

THIS FORM WILL BE HELD FOR A PERIOD OF 3 YEARS 


\section{Appendix D: School Principals Information sheet}

\section{Project Title}

Primary Teachers' Beliefs and Practices in relation to Grade Retention in Timor-Leste

Dear School Principals

My name is Cidalio Leite, I am conducting research as part of my Masters of Education Thesis for the School of Psychology and Pedagogy, Education College at Victoria University of Wellington.

I am writing to request your participation in research I am conducting on the topic Primary Teachers' Beliefs and Practices in relation to Grade Retention in Timor-Leste

I will be conducting a series of interviews in Timor-Leste from 21 November $2011-14$ of January 2012. I would like to interview a grade 1 teacher about: his/ her beliefs and practices in relation to Grade Promotion-Retention; Criteria and mechanisms he/she uses to promote-retain a student; the role of assessments; and strategies, if any, he/she uses to prevent student from being retained. I will also interview the school principals about their roles in relation to the practices of grade retention in Grade 1. In addition I wish to review school records that provide data relating to the number of students who have been retained in the previous two years. Beside interviews I would like to see the school documents in relation to grade retention.

\section{The aim of the research project}

The purpose of the research is to better understand the teacher' beliefs and practices in relation to grade retention in your school. 


\section{Project Procedures}

The interview will be conducted at an agreed upon date, time and place between the participant and researcher. The researcher will endeavour to accommodate the participant regarding these details as best possible.

The interview will be separately conducted between the principal and the teacher. It will take approximately 45 minutes to an hour each. The interview will be audio tape-recorded with the participant's consent. If for any reason the participant requests that the tape recording cease, then that wish will be respected. The interview will be transcribed later by myself.

Transcripts and audio tapes will not be made available to any body including school inspectors, superintendents and education directors at both district and national levels.

\section{Data Storage/Retention/Destruction/Future Use}

The gathered data will be collated from answers given in the interviews and school documents. The data will be shared only with my academic supervisor, and will be used only for this research. The data will be stored in a locked cabinet in Victoria University of wellington. Access to the data will be limited to myself and my academic supervisor. All data and materials will be destroyed after three years.

\section{Right to Withdraw from Participation}

Participants have the right to withdraw from the interview at any time, and to withdraw any data contributed by them up till $10^{\text {th }}$ January 2012. On completion of this thesis, all participants will receive a summary of finding. The participant may request to have the voice recorder turned off at any time. Contact with the researcher must be made by the teacher participant via phone or e-mail prior to this date.

\section{Anonymity and Confidentiality}

As per the signed consent form, code names will be used to ensure that the identities of participants and the information they disclose remain anonymous. If participants feel their identity at risk of becoming known, they may elect to exclude the name of the school they work for and/or their title within that school from the thesis and any other material published as a result of this thesis. 
The approval of the project

This project has been approved by the Victoria University Faculty of Education Ethics Committee.

Contact Details:

\begin{tabular}{|l|l|l|}
\hline Student researcher & Supervisor & Director \\
\hline Cidalio Leite & Dr. Jenny Horsley & Dr. Lex McDonald \\
School of Education Psychology and & School of Education Psychology & School of Education \\
Pedagogy, Faculty of & Psychology and Pedagogy, \\
Education,Victoria University of & Education, & Faculty of Education, \\
Wellington & Victoria University of & Victoria University of \\
33 Campbell St, Karori, Wellington & Wellington. & Wellington. Campbell St. \\
6172, NZ & Campbell St, Karori, Wellington & Karori, Wellington 6172, \\
Telephone in New Zealand: & 6172, & New Zealand \\
+640220140358 & New Zealand & Telp: +64 463 5173 \\
Telp in Timor-Leste: & Telp:+64 463 9704 & E-mail:1 \\
$+670-7254151$ & lexmcdonald@ vuw.ac.nz \\
E-mail: leitecida@myvuw.ac.nz & Jenny.Horsley@vuw.ac.nz & \\
\hline
\end{tabular}

For any queries regarding ethical concerns you may contact the Chair, Victoria University of Wellington Human Ethics Committee, Dr. Allison. Kirkman@vuw.ac.nz.

Yours Sincerely

Cidalio Leite

Master of Education Candidate (Student ID 300196535)

School of Education Psychology and Pedagogy

Faculty of Education

Victoria University of Wellington

This research has been assessed and approved by Victoria University of Wellington Faculty of Education Ethics Committee, proposal number SEPP/74/18896. 


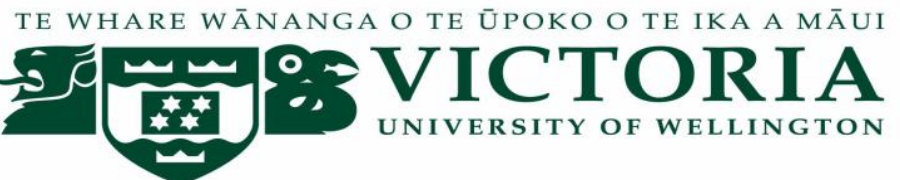

\section{Appendix E: School Principal's Consent Sheet for teacher}

Project Title: Primary Teachers' Beliefs and Practices in relation to Grade Retention in Timor-Leste

Name of Researcher: Cidalio Leite (Student ID: 300196535)

I have read the Participant Information Sheet and I understood the nature of the research and why my school has been selected. I have had the opportunity to ask questions and have had them answered to my satisfaction.

I agree for my Grade 1 teachers to be interviewed as part of this research.

I understand that Grade 1 teacher's participation in this study is entirely free.

$\square$ I understand that the Grade 1teachers are free to end their participation at any time, and to withdraw any data traceable to them at any time up until 10 January 2012

$\square$ I understand that the teachers will be audio-taped on consent, and that the tapes and transcripts will not be made available to either myself or school inspectors and Superintendents

$\square$ I understand that the transcripts of interviews will be translated into English by the researcher

I understand that teachers can request to stop the recording at any time.

I understand that the researcher will ensure the confidentiality of the teachers at all times.

$\square$ I understand that the data will be kept for 3 years, after which it will be destroyed.

$\square$ I understand that the Grade 1 teacher will be fully informed of the nature of this research and be required to give signed consent.

$\square$ In understand that the names and identities of the participant and the name of his/her school and communities will not be identified in the research.

Name:

Signature:

Date: 
This research has been assessed and approved by Victoria University of Wellington Faculty of Education Ethics Committee, proposal number SEPP/74/18896.

\section{THIS FORM WILL BE HELD FOR A PERIOD OF 3 YEARS}




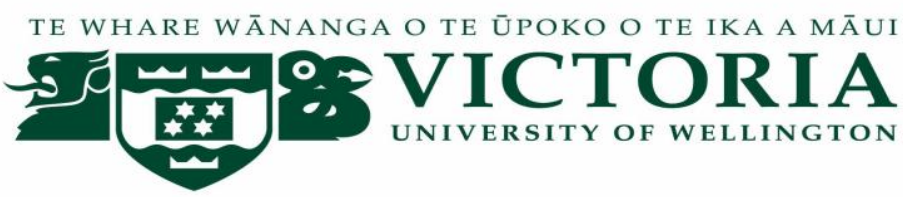

\section{Appendix F: School Principal's Consent Sheet as Participant}

Project Title: Primary Teachers' Beliefs and Practices in relation to Grade Retention in Timor-Leste

Name of Researcher: Cidalio Leite (Student ID: 300196535)

I have read the Participant Information Sheet and I understood the nature of the research and why I have been selected. I have had the opportunity to ask questions and have had them answered to my satisfaction.

I am fully informed about the nature of this research

I agree to take part in this research.

I understand that my participation in this study is entirely voluntary

I agree to be audio-taped, and understand that the recorded interviews will be transcribed and translated into English by the researcher

I understand that the audio-taped interviews and transcriptions will not make available to any of my superiors

I understand that recordings can be stopped at any time on request.

I understand that I am free to end my participation at any time, and to withdraw any data traceable to me at any time up till $10^{\text {th }}$ January 2012

I understand that the researcher will ensure confidentiality at all times.

I understand that my name and identities and the name of this school and community will not be identified in the research

I understand that I will receive a summary of the findings upon the completion of the thesis.

I understand that the data I provide will be kept for 3 years, after which it will be destroyed.

Name:

Signature:

Date: 
This research has been assessed and approved by Victoria University of Wellington Faculty of Education Ethics Committee, proposal number SEPP/74/18896.

THIS FORM WILL BE HELD FOR A PERIOD OF 3 YEARS 


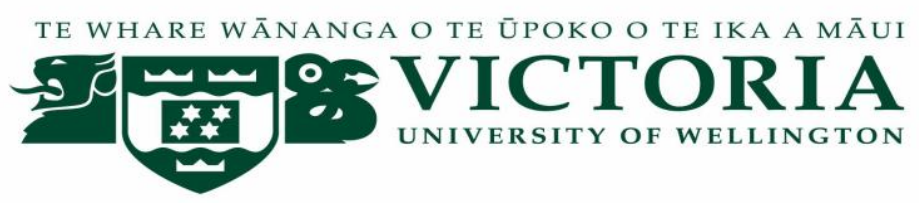

\section{Appendix G: Teacher's Information Sheet}

Project Title: Primary Teachers' Beliefs and Practices in relation to Grade Retention in Timor-Leste

Dear teachers

My name is Cidalio Leite and I am conducting research as part of my Masters of Education Thesis for the School of Psychology and Pedagogy, Faculty of Education at Victoria University of Wellington.

I am writing to request your participation in research I am conducting on the topic Primary Teachers' Beliefs and Practices in relation to Grade Retention in Timor-Leste.

I will be conducting a series of interviews in Timor-Leste from 21 November 2011-14 January 2012. I would like to interview you about: your beliefs and practices in relation to Grade PromotionRetention; Criteria and mechanisms you use to promote-retain a student; the role of assessments; and strategies, if any, he/she use to prevent student from retention. In addition I wish to review school records that provide data relating to the number of students who have been retained in the previous two years

My study aims to better understand your beliefs and practices in relation to grade retention in your school, so there is no right or wrong answer. You have been selected as you are a teacher who has experience in practices in relation to grade promotion and retention in general, especially in grade 1 classes.

I would like to speak with you about your experiences on this topic for approximately 45 minutes to an hour. I will record our conversations; however, this will only be done with your consent. If you feel uncomfortable about the interview being recorded, the tape recorder can be switched off at any time. I will also take some notes. You will have a chance to check the transcripts of this interview. 
Likewise, your participation in this research is on a purely voluntary basis. If at any stage during the interview you change your mind and want to stop, then I will accept this without question. If you decide after the interview that you no longer want to be a participant, please let me know by 10 January 2012, and I will destroy all information that I have collected from you.

I want to reassure you that all participants will be given a pseudonym, and any information you provide will be completely confidential and protected. The Consent Form and the data that you provide will be kept fully confidential and stored in a locked cabinet in Victoria University of Wellington. No third party will have access to your personal information and data. The data will be destroyed after 3 years by deleting the relevant files from the computer. All participants will be given a pseudonym I would greatly appreciate and value your participation in this study. If you have any questions you would like to ask before commencing, please do not hesitate to ask me. If you agree to participate, please sign the consent form before we commence the interview.

Yours sincerely

Cidalio Leite

Master of Education Candidate (Student ID 300196535)

School of Education Psychology and Pedagogy

Faculty of Education

Victoria University of Wellington

This research has been assessed and approved by Victoria University of Wellington Faculty of Education Ethics Committee, proposal number SEPP/74/18896. 


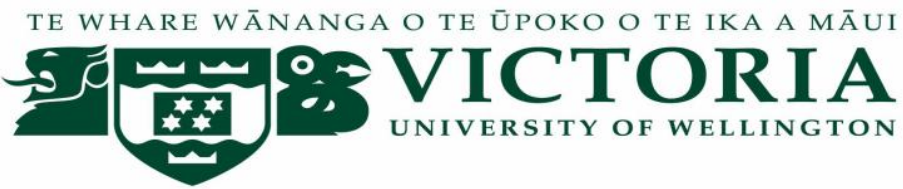

\section{Appendix H: Teacher's Consent Sheet}

Project Title: Primary Teachers' Beliefs and Practices in relation to Grade Retention in Timor-Leste

Name of Researcher: Cidalio Leite (Student ID: 300196535)

I have read the Participant Information Sheet and I understood the nature of the research and why I have been selected. I have had the opportunity to ask questions and have had them answered to my satisfaction.

I am fully informed about the nature of this research

I agree to take part in this research.

I understand that my participation in this study is entirely voluntary

I agree to be audio-taped, and understand that the recorded interviews will be transcribed an translated into English by the researcher.

I understand that the audio-taped interviews and transcriptions will not make available to any of my superiors.

I understand that recordings can be stopped at any time on request.

I understand that I am free to end my participation at any time, and to withdraw any data traceable to me at any time up till $10^{\text {th }}$ January 2012

I understand that the researcher will ensure confidentiality at all times.

$\square \quad$ I understand that my name and identities and the name of this school and community will not be identified in the research

I understand that I will receive a summary of the findings upon the completion of the thesis.

I understand that the data I provide will be kept for 3 years, after which it will be destroyed.

Name:

Signature:

Date:

This research has been assessed and approved by Victoria University of Wellington Faculty of Education Ethics Committee, proposal number SEPP/74/18896.

THIS FORM WILL BE HELD FOR A PERIOD OF 3 YEARS 
Appendix I: An example of exam text in Portuguese language

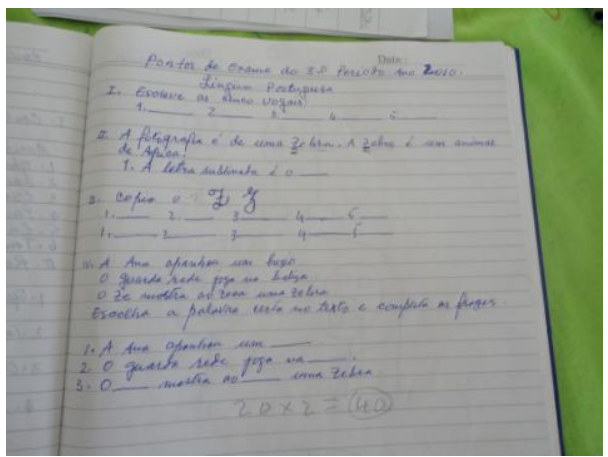


Appendix J: A student was retained had 43 band scores

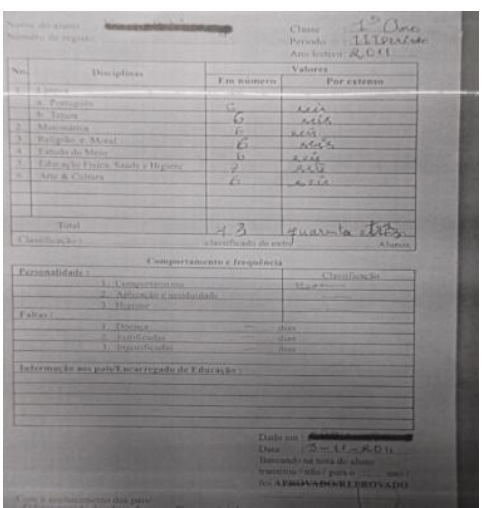


Appendix K: Unclear exam instruction

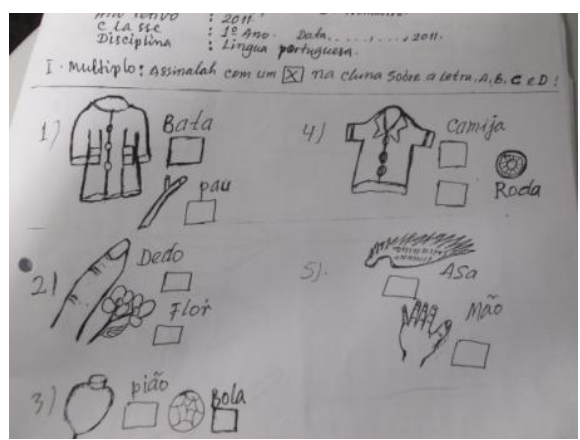


Appendix L: An unclear student's work was given a score of 6

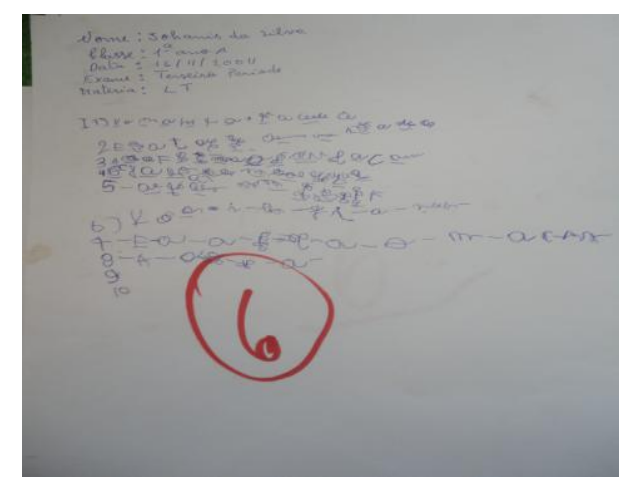


Appendix M: A wrong maths equation was given a correct sign

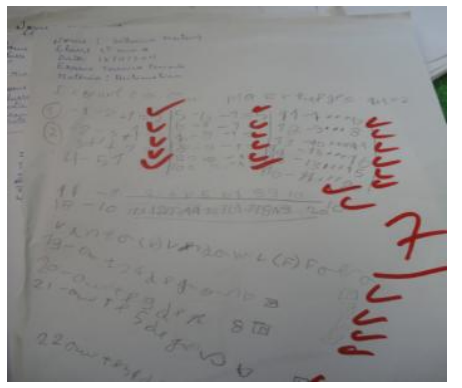


Appendix N: An irrelevant exam question

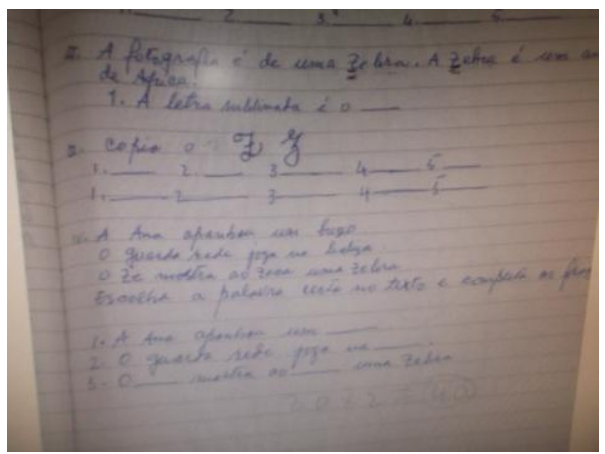

